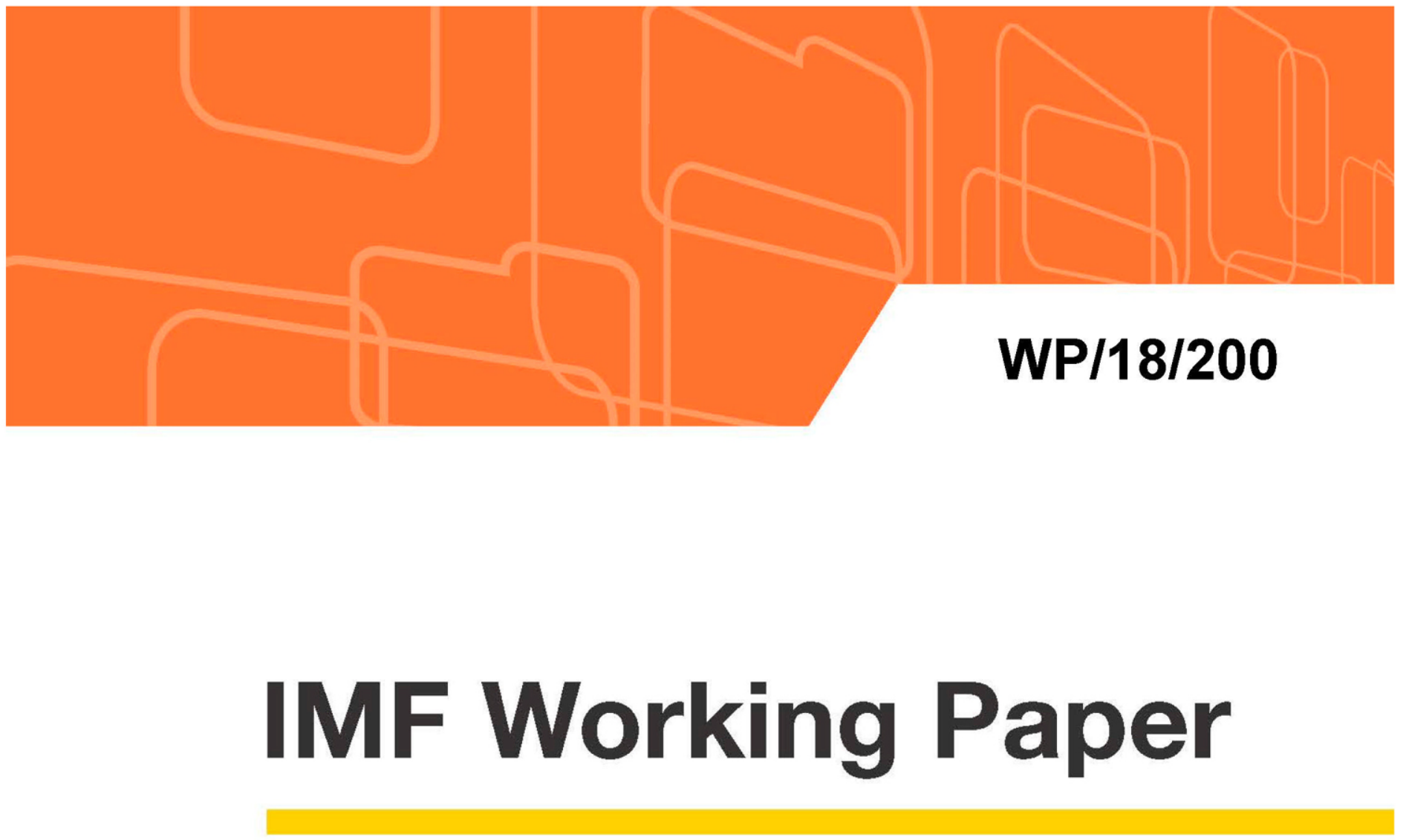

\title{
Dollarization and Financial Development
}

by Geoffrey Bannister, Malin Gardberg and Jarkko Turunen

IMF Working Papers describe research in progress by the author(s) and are published to elicit comments and to encourage debate. The views expressed in IMF Working Papers are those of the author(s) and do not necessarily represent the views of the IMF, its Executive Board, or IMF management. 


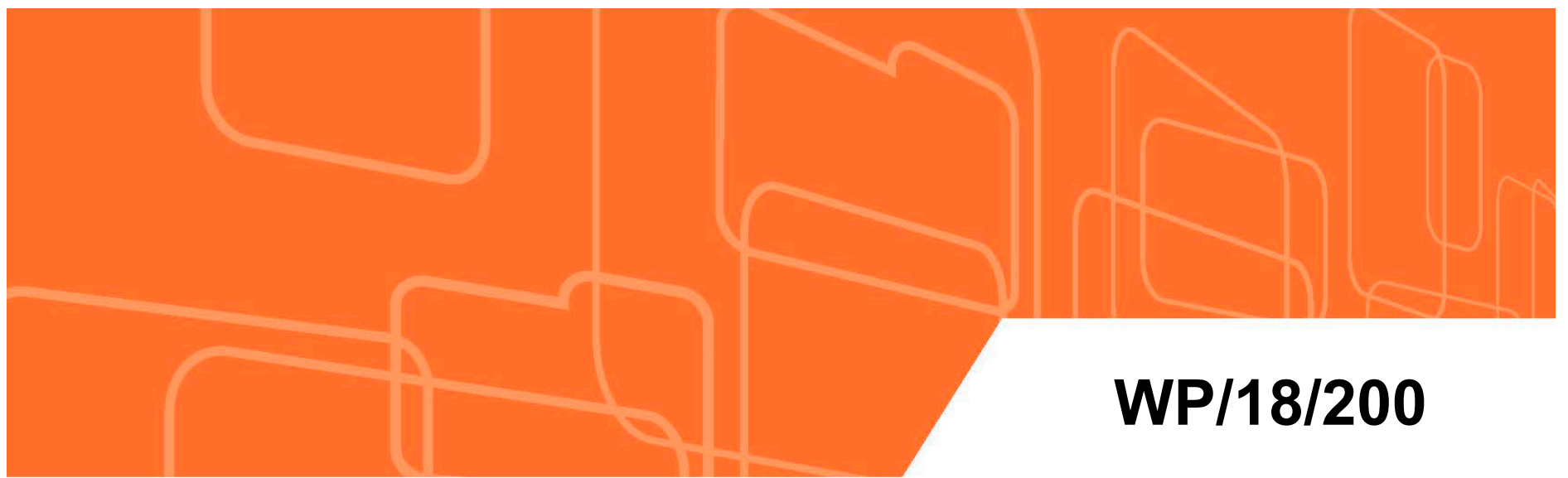

IMF Working Paper

Dollarization and Financial Development

by Geoffrey Bannister, Malin Gardberg and Jarkko Turunen

IMF Working Papers describe research in progress by the author(s) and are published to elicit comments and to encourage debate. The views expressed in IMF Working Papers are those of the author(s) and do not necessarily represent the views of the IMF, its Executive Board, or IMF management.

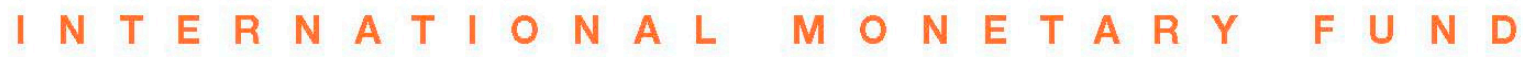




\title{
IMF Working Paper
}

Asia and Pacific Department

\section{Dollarization and Financial Development}

\section{Prepared by Geoffrey Bannister, Malin Gardberg and Jarkko Turunen}

Authorized for distribution by Alex Mourmouras

September 2018

\begin{abstract}
IMF Working Papers describe research in progress by the author(s) and are published to elicit comments and to encourage debate. The views expressed in IMF Working Papers are those of the author(s) and do not necessarily represent the views of the IMF, its Executive Board, or IMF management.
\end{abstract}

\begin{abstract}
Despite significant strides in financial development over the past decades, financial dollarization, as reflected in elevated shares of foreign currency deposits and credit in the banking system, remains common in developing economies. We study the impact of financial dollarization, differentiating across foreign currency deposits and credit on financial depth, access and efficiency for a large sample of emerging market and developing countries over the past two decades. Panel regressions estimated using system GMM show that deposit dollarization has a negative impact on financial deepening on average. This negative impact is dampened in cases with past periods of high inflation. There is also some evidence that dollarization hampers financial efficiency. The results suggest that policy efforts to reduce dollarization can spur faster and safer financial development.
\end{abstract}

JEL Classification Numbers: G10, G20 and O16

Keywords: dollarization, financial development, financial deepening, financial inclusion and developing economies

\footnotetext{
${ }^{1}$ This paper was prepared while Malin Gardberg was a summer intern in the Asia and Pacific Department. Authors would like to thank seminar participants at the IMF, as well as Adolfo Barajas, Benedict Baduel, Evrim Bese Goksu, Qiaoe Chen, Marco Espinosa, Daniel Hardy, Fah Jirasavetakul, Lilia Kadyrberdieva, Padamja Khandelwal, Hui Miao, Alex Mourmouras, Lorraine Ocampos, Lorenzo Pozzi, Andrea Presbitero, Sergio Rodriguez, Kevin Ross and Kazuko Shirono for helpful comments. We would also like to thank Albe Gjonbalaj and Ross Rattanasena for excellent assistance.
} 
Author's E-Mail Address: gbannister@imf.org, malin.gardberg@ifn.se and jturunen@imf.org 


\section{Contents}

$\begin{array}{lr}\text { Abstract } & \underline{2} \\ \text { I. INTRODUCTION } & \underline{5} \\ \text { II. LITERATURE AND THEORY } & \underline{6} \\ \text { III. MEASURING DOLLARIZATION AND FINANCIAL DEVELOPMENT } & \frac{9}{2} \\ \text { IV. METHOD } & \underline{13} \\ \quad \text { Policy variables in P } & \underline{13} \\ \quad \text { Structural variables in S } & \underline{13} \\ \quad \text { Dollarization variables in D } & \underline{14} \\ \quad \text { Estimation strategy } & \underline{15} \\ \text { V. RESULTS } & \underline{15} \\ \quad \text { Financial Depth } & \underline{22} \\ \quad \text { Financial Access and Efficiency } & \underline{24} \\ \quad \text { Robustness } & \underline{24} \\ \text { VI. CONCLUSION } & \underline{27} \\ \text { VII. REFERENCES } & \end{array}$

TABLES

1. The Impact of Dollarization on Financial Debt

2. Dollarization and Financial Development in Countries with a History of High Inflation

3. Dollarization and Financial Access and Efficiency $\underline{23}$

FIGURES

1. Deposit and Credit Dollarization $\underline{9}$

2. Regional Average Deposit Dollarization

3. Regional Average Credit Dollarization

4. Deposit Dollarization in a Number of Countries

5. Deposit vs. Credit Dollarization __ 10

6. Deposit Dollarization and Financial Development___

7. Credit Dollarization and Financial Development 11

8. Aggregate Mismatch between Deposit and Credit Dollarization and Financial Development $\underline{12}$

9. Deposit Dollarization in Foreign Asset Ratios of Deposit Taking Banks $\underline{19}$

APPENDIX I: DATA _ _ $\underline{30}$

Country coverage

Dollarization _ $\underline{30}$

Financial development

Control and additional variables __ $\underline{31}$

TABLE 
1. Summary Statistics

\section{TABLES}

1. Dollarization and Financial Development with Dollarization and Its Determinants Predetermined

2. Dollarization and Financial Development Relationship Estimated with Fewer Instruments $\underline{35}$

3. Dollarization and Financial Development Using More Parsimonious Models $\underline{36}$

4. Deposit Dollarization and Financial Depth, Access and Efficiency with FE and Difference GMM Estimators $\underline{37}$

5. The Relationship between Dollarization and Financial Development in Countries with Deposit and Credit Dollarization Above 1 Percent $\underline{38}$ 


\section{INTRODUCTION}

Developing economies have made significant strides in financial development over the past decades, including through financial deepening, improvements in financial inclusion and banking sector efficiency. Financial development has, in turn, supported higher economic growth in these countries (Levine, 2005). At the same time, financial dollarization, defined as the share of foreign currency deposits/credit in total deposits/credit, remains a common and persistent phenomenon. For example, average deposit dollarization across our sample of partially dollarized developing economies was around 30 percent in 2015.

The coexistence of financial development on the one hand and dollarization on the other raises questions about the impact of foreign currency use in financial transactions on financial deepening, inclusion and efficiency. The negative aspects of partial dollarization are well documented, including risks related to currency mismatches and balance sheets (Baliño et al., 1999 and Eichengreen, 2001) and weaker monetary policy transmission (Levy Yeyati, 2006). Partial dollarization has also been associated with significant financial stability risks (see, for example Gulde et al., 2004). However, a number of authors (e.g. Hausmann, 1999; De Nicolo et al, 2005; and Levy Yeyati, 2006) have also raised the possibility that, in providing financial solutions to economic agents in less-than-optimal policy environments, dollarization can support greater financial development.

We study the impact of partial (unofficial) dollarization on financial development in developing economies. ${ }^{23}$ We refer to financial deepening, as measured by the credit-to-GDP ratio, as the readily available aggregate measure of financial development that is also closely related to economic activity. However, in line with the suggestion in recent literature (e.g. Sahay et al., 2015) that financial development is a multidimensional concept, we also examine the impact of dollarization on financial access and banking sector efficiency. We also differentiate across foreign currency deposits and credit. While the two empirical measures of dollarization are often closely correlated (see below), there are important differences in the levels of these two variables that are likely driven by both market factors -- differences in supply and demand for foreign currency deposits and loans - and regulatory factors -- such as restrictions on foreign currency lending.

We bring to bear a new dataset for a sample of 77 emerging and developing countries over the period 1996-2015 (see Appendix I for a detailed description). Our dataset covers more countries and a longer time period (including the global financial crisis and its aftermath) than data used in

\footnotetext{
${ }^{2}$ We use the term "dollarization" to refer to the use of any foreign currency other than the legal tender, not just the dollar. Full (official) dollarization where the foreign currency is the sole legal tender, is typically adopted by countries to stabilize inflation and to promote fiscal discipline. It does not involve a currency choice by firms and households, a common feature in countries with partial dollarization.

${ }^{3}$ We follow most of the literature in defining dollarization as the ratio of non-local currency deposits in total deposits, and nonlocal currency credit over total credit, in the banking system. We do not consider non-bank financial institutions (insurance funds or pension funds, for example), and we do not include off-shore transactions or assets and liabilities to non-residents. We also do not include loans denominated in domestic currency but indexed to the exchange rate.
} 
previous studies. Following Barajas et al., (2013), we study the relationship between financial development and dollarization in a framework that takes into account the joint policy and structural determinants of financial development. Finally, the large panel dataset allows us to study the impact of dollarization using dynamic panel GMM estimation, thus controlling for potential endogeneity of the regressors.

Our results show that financial dollarization, and deposit dollarization in particular, has a negative impact on financial development. Specifically, we find that dollarization slows down financial deepening. These results are robust to alternative specifications and estimation methods. The negative impact of deposit dollarization on financial depth may reflect the fact that a share of foreign currency deposits are transferred overseas, rather than returned to the domestic economy as private credit, thus contributing to a shallower domestic financial sector. It could also reflect the existence of additional costs that inhibit further financial deepening in markets where financial assets and liabilities are denominated in two or more currencies. Our results, using a larger sample of countries and including data for more recent time periods, are broadly consistent with results in De Nicolo, Honohan and Ize (2005) and Court, Ozsoz and Rengifo (2012). We also find that, similar to De Nicolo, Honohan and Ize (2005), the negative impact of dollarization on financial deepening is dampened somewhat in countries with past experiences of very high inflation. Therefore, there may be country cases where dollarization helps mitigate the negative impact of past macroeconomic instability on financial development. We also find some evidence that dollarization has a negative impact on financial efficiency. Our estimations indicate that net interest margins are positively related to levels of dollarization, suggesting a negative effect on financial efficiency. However, results across model specifications vary, suggesting caution in interpreting this result. Finally, we find no evidence of an association between financial dollarization and financial access in our data.

The rest of the paper is organized as follows. In section II we review existing literature on dollarization and financial development. We then discuss available measures of dollarization and financial development in section III and empirical methods in section IV. We present our main results in Section $\mathrm{V}$, with focus on the impact of dollarization on financial deepening, followed by the impact on other measures of financial development. Results from multiple robustness checks

are included in Appendix II. We conclude with a summary of main results and policy implications in Section VI.

\section{LITERATURE AND THEORY}

Following Ize and Levy Yeyati (2006), we look at dollarization as the outcome of a financial equilibrium between creditors and borrowers that optimize the currency composition of their contracts, in response to certain features of the economic environment.

The portfolio approach (Ize and Levy Yeyati, 2003) explains dollarization as a reaction to macroeconomic instability, as manifest in high inflation and exchange rate volatility. Under this approach, the domestic investor chooses the composition of investments to minimize the variance of expected returns, which depend on the volatility of inflation and the real exchange rate. This is 
in line with ample evidence that episodes of high inflation and real exchange rate depreciations are associated with increases in dollarization. An implication of this approach is that expectations have an important role to play, and the credibility of monetary policy and the exchange rate regime are key (Levy Yeyati, 2006). The lack of credible monetary policy and exchange rate regimes explain the persistence of dollarization, even after inflation has been tamed, usually by relying on a stable real exchange rate as a nominal anchor. Following this approach, not surprisingly, a number of authors have found that dollarization is associated with weak economic institutions (De Nicolo et al. 2005; Levy Yeyati, 2006).

The portfolio approach can be extended to the currency choice related to total incomes, rather than just financial investments. In this case, in an environment where exchange rate depreciations are contractionary, economic agents prefer foreign currency (e.g. dollars) to maintain the real value of their consumption in the face of macroeconomic uncertainty. The existence of balance sheet mismatches in highly dollarized economies tends to reinforce the contractionary effect of exchange rate deprecation, thus also explaining the persistence of dollarization (Ize and Levy Yeyati, 2005).

A second feature that explains dollarization is the existence of market frictions or failures in credit markets. For example, Jeanne (2000) highlights how a local currency premium induced by devaluation expectations (i.e. a peso problem) leads to dollarization when liquidations are costly (the relevant market friction). Under this situation, higher credit risk on local currency loans leads creditors to prefer to lend in dollars. At the same time, this can lead to "fear of floating" or limited exchange rate flexibility to limit the effects of currency risk on creditors' portfolios. Moral hazard, related to government guarantees or other forms of regulation in the presence of asymmetric payoffs, can also lead to dollarization, to the extent that they insure dollar creditors and borrowers from large losses in the event of a large depreciation (e.g. Burnside et al., 2001). Barajas and Morales (2003) also point to factors such as the relative market power of borrowers and central bank intervention in foreign exchange markets. The role of incomplete credit markets is also highlighted by the fact that the presence of foreign banks tends to be associated with higher dollarization. For example, Basso, Calvo-Gonzalez and Jurgilas (2011) suggest that in European transition economies there is a strong link between financial deepening, cross border banking activities and dollarization.

Empirical studies of de-dollarization also support the idea that financial dollarization has its source in both macroeconomic stability concerns and frictions in credit markets. Kokenyne et al. (2010), Garcia-Escribano and Sosa (2011) and Catao and Terrones (2016) confirm the importance of credible macroeconomic stabilization policies to lower inflation and stabilize the exchange rate as a key component of successful de-dollarization strategies in Europe and Latin America. These authors also refer to differential prudential regulations to lower bank's incentives to transact in foreign currencies and to provide incentives for economic agents to internalize the risks of foreign currency lending and deposits. These policies have been pursued in a number of Latin American and Asian economies and include raising provisions for foreign currency loans, tighter capital requirements against open foreign exchange positions, differentiated reserve requirements and remuneration on foreign currency deposits, among others (see for example Catao and Terrones 
(2016) and Kokenyne et al. (2010)). A third component of successful de-dollarization is the development of local currency capital markets, which provide alternate vehicles for longer term investment and savings.

In all these cases, financial dollarization is a response to a suboptimal policy environment, be it macroeconomic instability or underdeveloped local credit markets. A natural question is whether dollarization, in providing a solution for economic agents, opens the way for greater financial development (i.e. depth and access) or efficiency. For example, Hausmann (1999) speculates that dollarization could expand the menu of financial options available to agents and in so doing improve financial stability.

There has been little or no treatment of this question in theory, but a number of authors have attempted to investigate this issue empirically, albeit with conflicting results. De Nicolo, Honohan and Ize (2005) posit that since dollarization offers an inflation hedge for transactions it should therefore facilitate more financial transactions on-shore than would otherwise take place. ${ }^{4}$ They regress financial depth (M2/GDP) on a number of instruments that include the main underlying determinants of dollarization (regulatory, macroeconomic and institutional), and find that dollarization is not associated with deeper financial markets, except in high inflation countries. Following De Nicolo et al. (2005), Levy Yeyati (2006) regresses financial depth on a dollarization legal restrictions index (as an instrument for dollarization) and finds a positive relationship that is significant at the 5 percent level, which could be interpreted as evidence that more dollarization is associated with shallower financial markets. Court, Ozsoz and Rengifo (2012) study forty-four dollarized banking systems using two-stage least-squares to deal with endogeneity, and find that dollarization has a consistent and significant negative coefficient on financial deepening. On the other hand, Reinhart, Rogoff and Savastano (2014), studying different aspects of dollarization in a sample of emerging and developing countries, find that the joint existence of domestic dollarization and external liability dollarization appears to have a positive effect on financial deepening.

There have been even fewer systematic investigations of the effects of dollarization on financial access or efficiency. To our knowledge, the only study in this area is Honohan and Shi (2001), who look at the relationship between dollarization, the supply of credit, interest rates and spreads. They find that banks tend to place as much as half of dollar deposits they receive off-shore, due to limits on safe and profitable foreign exchange lending in the local market, thus potentially limiting the supply of credit in the local market. They also find that net interest margins rise (i.e. efficiency is lower) with higher dollarization, potentially due to market power of dollarized banks in the system.

\footnotetext{
${ }^{4}$ This is also supported by overwhelming evidence that countries that force conversion of dollar deposits into local currency experience a large contraction in intermediation (Savastano, 1996; Baliño et al., 1999).
} 


\section{MEASURING DOLLARIZATION AND FINANCIAL DEVELOPMENT}

In this study we look at two different measures of partial dollarization -- deposit and credit dollarization. ${ }^{5}$ We define deposit dollarization as the ratio of dollar-denominated deposits to total broad money deposits, and credit dollarization as the ratio of dollar-denominated loans to total loans. ${ }^{6}$

Both deposit and credit dollarization have diminished over the sample period (between 1996 and 2015) (Figure 1). The Eastern European transition economies are generally more dollarized than the average country in the sample, and the jump in dollarization between 1996 and 1997 comes from the inclusion of the transition economies in the sample. The average deposit dollarization in our sample of 77 emerging market and developing countries has also been higher than average credit dollarization. There is significant geographical dispersion. Dollarization, and in particular deposit dollarization, is a prominent phenomenon in the Latin American countries in addition to the European transition economies, and much less common in the MENA or African countries (Figures 2 and 3). Dispersion in dollarization across countries is also large: Cambodia and Nicaragua are almost fully dollarized with dollarization levels around 90 percent, whereas other countries like China and Bangladesh currently have close to zero dollarization (Figure 4). Although the level of dollarization has stayed fairly stable or declined somewhat in most countries over the sample period, there are some notable exceptions. Albania has experienced a surge in dollarization in the past years, whereas Bolivia, Bosnia, Angola and Peru have managed to dedollarize their economies substantially since $2000 .^{7}$ Finally, although the correlation between
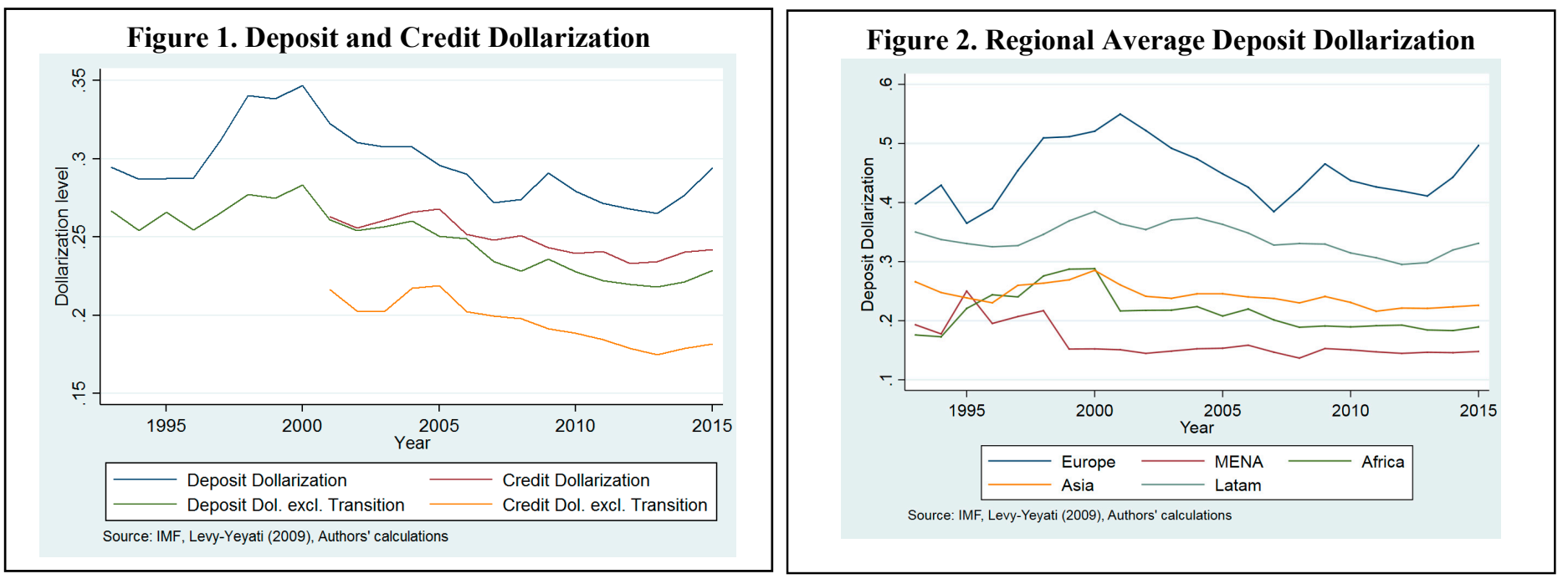

\footnotetext{
${ }^{5}$ A more complete measure of dollarization would also account for foreign currency cash holdings. However, owing to limited data availability for foreign cash holdings across countries, we focus on deposit and credit dollarization.

${ }^{6}$ A full description of the data is provided in Appendix I.

${ }^{7}$ Garcia-Escribano and Sosa (2011) and Catao and Terrones (2016) discuss the de-dollarization experience in Peru. They stress the importance of credible macroeconomic stabilization policies to lower inflation and stabilize the exchange rate, as well as the supporting roles of prudential regulations and development of local financial markets.
} 
deposit and credit dollarization in our sample is fairly high at 82 percent there is still a lot of variation in the difference across countries (Figure 5).
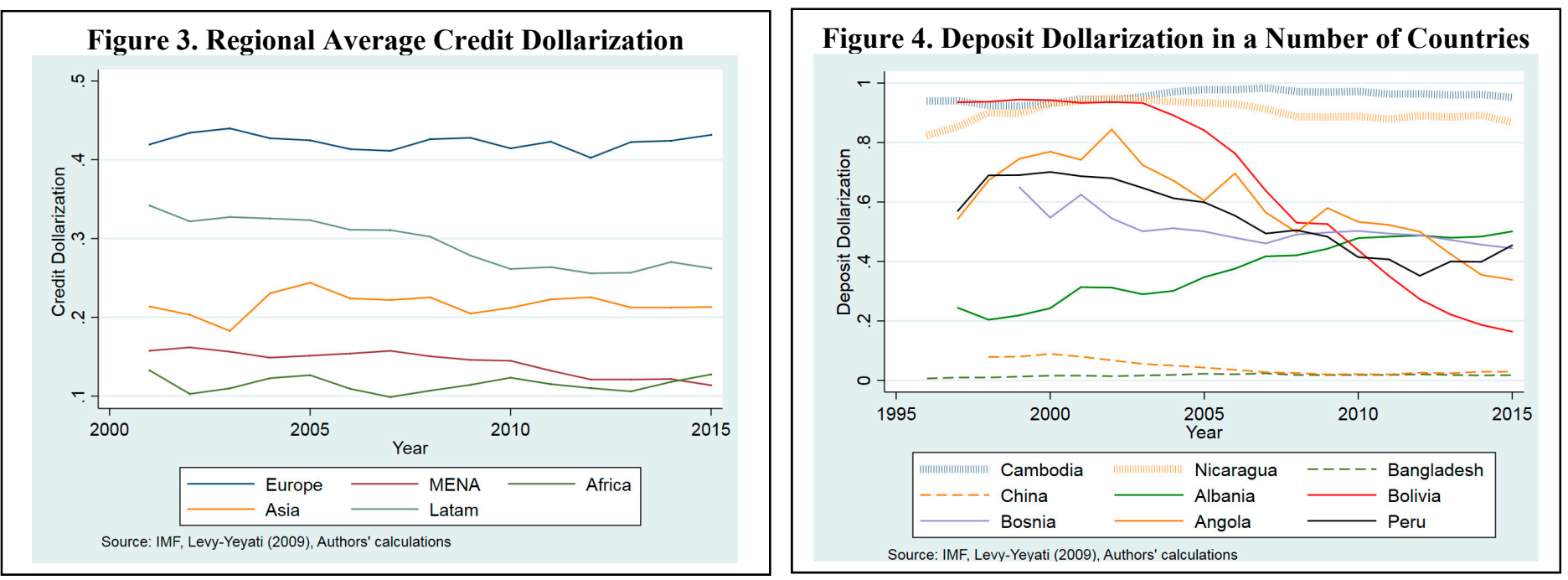

Financial development is a broad concept. In line with the emerging consensus in the recent literature that financial development is a multidimensional concept (e.g. Sahay et al., 2015) we focus on three dimensions: financial depth, access and efficiency. The log of private credit to GDP is used to measure financial depth. While higher credit to GDP is usually consistent with a larger and more developed financial sector, financial depth in itself does not guarantee financial access or efficiency. We consequently also look at the impact of dollarization on access to financial services and financial efficiency.

Figure 5. Deposit vs. Credit Dollarization

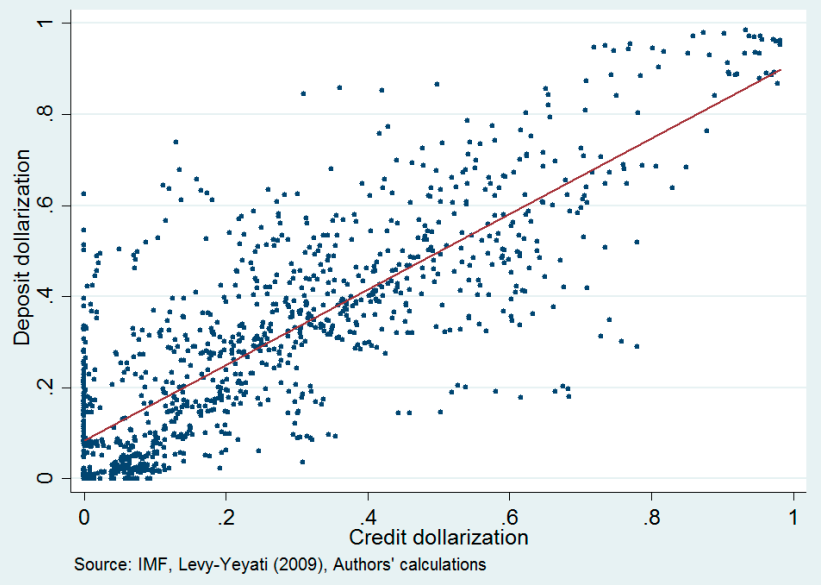

Financial access is represented by the log of bank accounts per 1000 adults, where a higher number of accounts in the adult population reflects better access to financial services. The bank net interest margin, defined as the accounting value of bank's net interest revenue as a share of its average interest-bearing assets, reflects how efficient the financial sector is in providing financial intermediation to the economy. Net interest margins tend to be substantially higher in developing countries than in developed countries. High interest margins often reflect market frictions, institutional and regulatory inefficiencies, information asymmetries, high fixed costs, imperfect banking sector competition and entry barriers, or a large vulnerability to macroeconomic variables such exchange rate, interest rate and real economic fluctuations (Stiglitz and Weiss 1981, Beck and Hesse 2009). Although a higher net interest margin is desirable from an individual bank's point of view, a lower net interest margin signals that the financial sector is more efficient in offering financial services to the society. Binned scatterplots of dollarization and the different dimensions of financial 
development suggest that a higher level of dollarization, particularly deposit dollarization, and a positive difference between aggregate deposit and credit dollarization, is associated with lower levels of financial depth, access and efficiency (Figures 6 to 8).

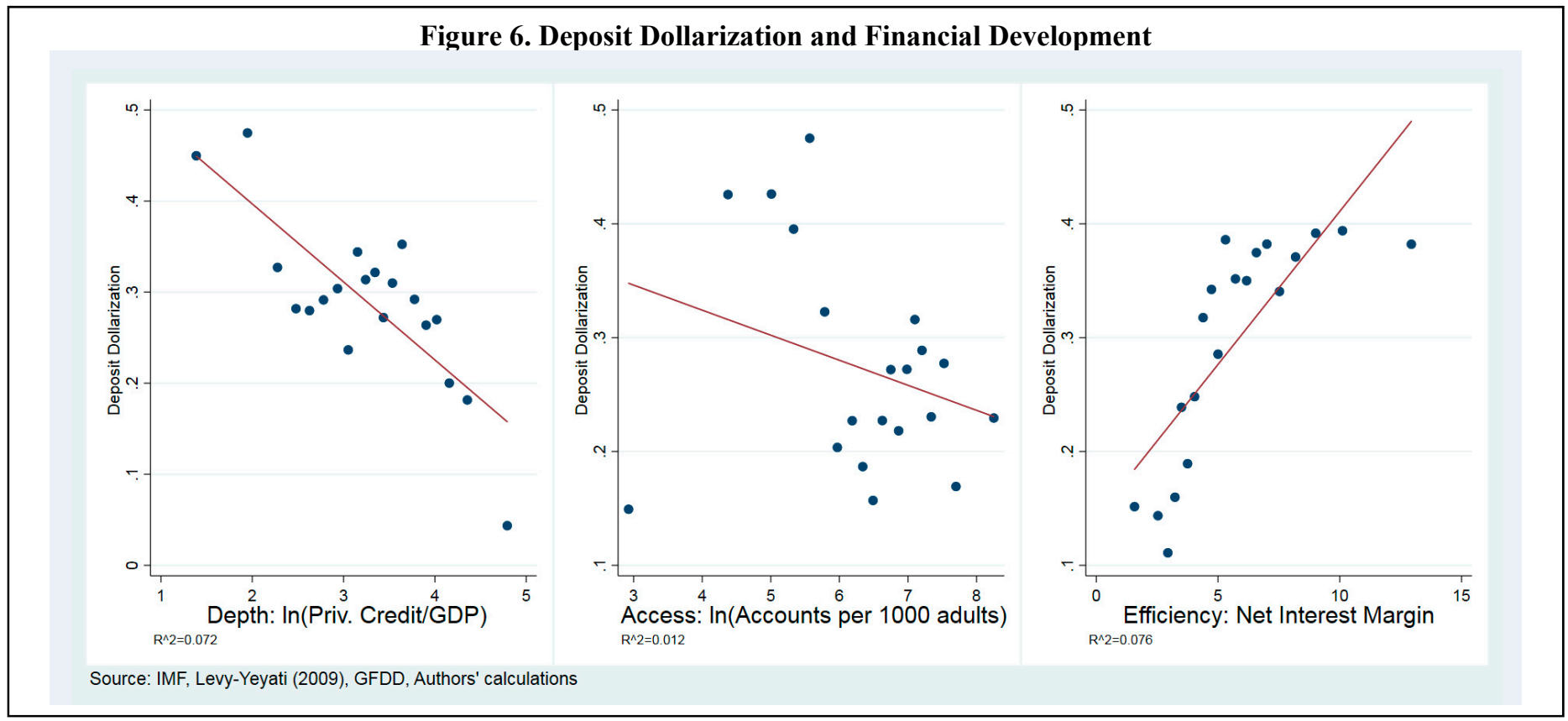

Figure 7. Credit Dollarization and Financial Development
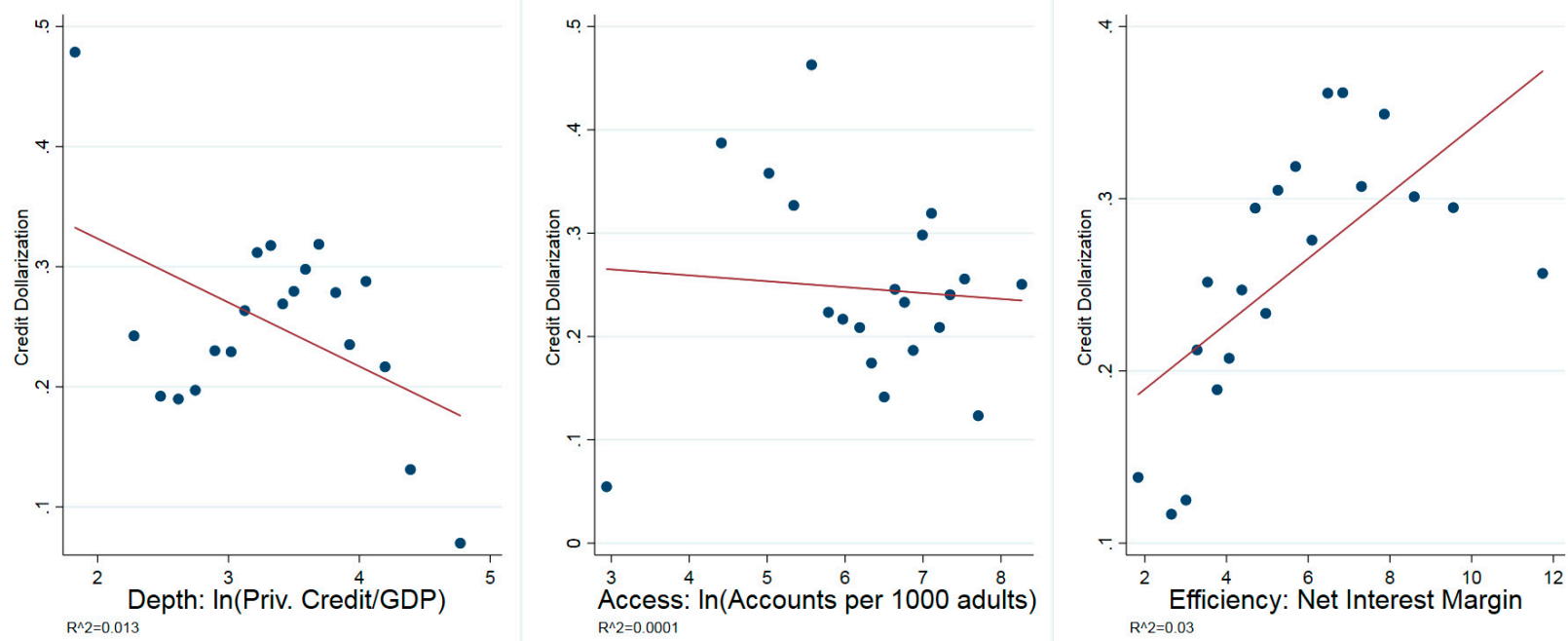

Source: IMF, Levy-Yeyati (2009), GFDD, Authors' calculations 
Figure 8. Aggregate Mismatch between Deposit and Credit Dollarization and Financial Development
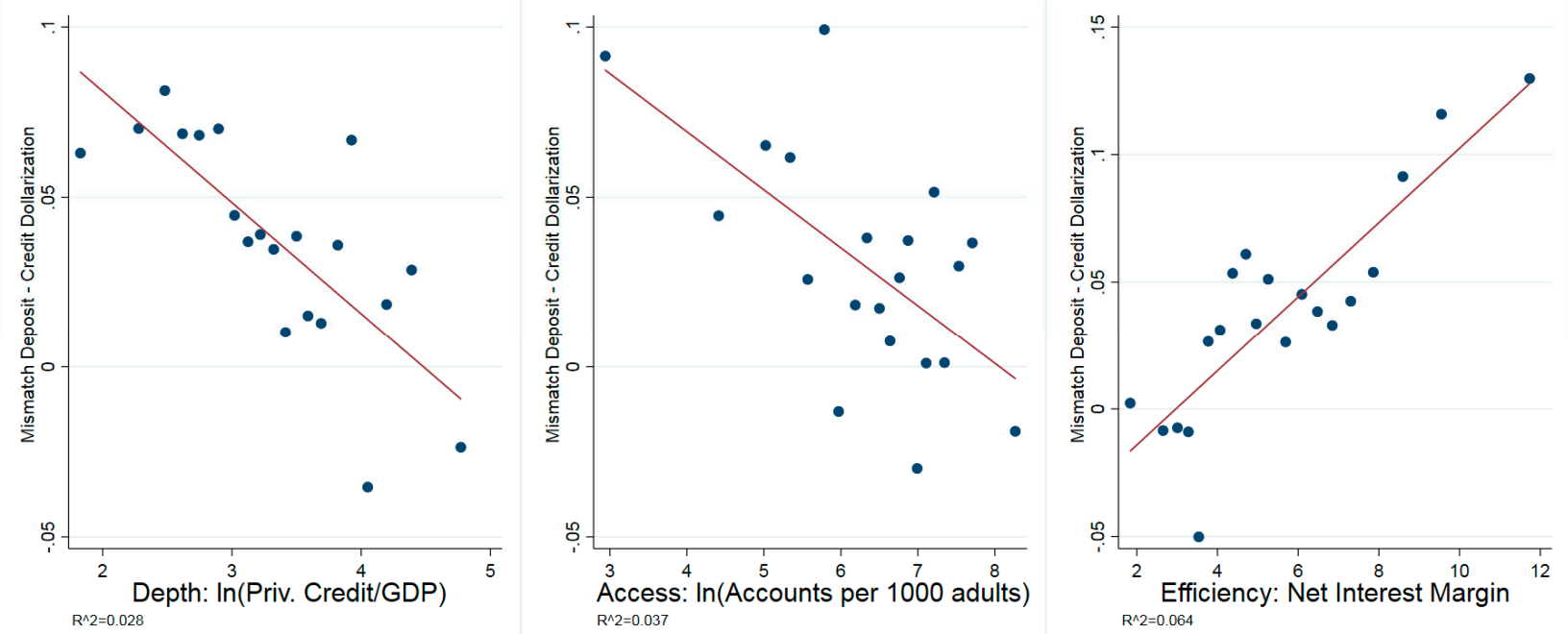

Source: IMF, Levy-Yeyati (2009), GFDD, Authors' calculations

\section{METHOD}

We use panel data analysis on our sample of 77 countries over the time period 1996-2015 to investigate the relationship between dollarization and financial development. The baseline panel models that we use aim to identify the impact of both credit and deposit dollarization on financial depth (PrivCred), access (Accounts) and efficiency (NetIntMarg).

The literature has identified several factors that have an impact on financial development. To ensure that we properly identify the impact of dollarization on financial development, we include both structural and macroeconomic policy variables as controls. Moreover, to make sure that we capture the underlying causes of dollarization that might be related to our financial development indicators, we also include variables from the literature associated with dollarization. The baseline equation which identifies the relationship between dollarization and the financial development indicator $F D_{i, t}$ in country $i$ in year $t$ is therefore specified as:

$$
F D_{i, t}=\alpha F D_{i, t-1}+\beta D o l_{i, t}+\boldsymbol{P}_{i, t}^{\prime} \gamma+\boldsymbol{S}_{i, t}^{\prime} \theta+\boldsymbol{D}_{i, t}^{\prime} \rho+\mu_{i}+\delta_{t}+\varepsilon_{i, t} \quad(1)
$$

where $D_{o l}$ is a measure of either deposit dollarization (DepDol) or credit dollarization $(C r e d D o l), \mathbf{P}$ is a vector of policy variables that reflect the policy environment influencing financial development, $\boldsymbol{S}$ is a vector of structural variables that have an impact on financial development, $\boldsymbol{D}$ is a vector of variables that have an impact on dollarization, $\beta, \gamma$ and $\theta$ contain the estimated coefficients, $\mu_{i}$ represents the country fixed effect, $\delta_{t}$ the time varying global component and $\varepsilon$ the stochastic error term. As financial development is persistent, the lag of the dependent variable is also included. The coefficient of interest is $\beta$, which measures the impact of dollarization on financial development. 


\section{Policy variables in $\boldsymbol{P}$}

A wide range of policy variables have been found to impact financial development. ${ }^{8}$ The policy variables in $\boldsymbol{P}$ can be divided into variables measuring macroeconomic developments, financial market regulation and structure, and institutional quality. The macroeconomic variables used are the log changes of real GDP per capita (GDP growth), CPI inflation (Inflation), and a banking crisis dummy (Banking Crisis). The market share of the three largest financial institutions in the country (3 Bank Conc), is used as a proxy for financial market structure, an index of capital account openness (KaOpen) is used to control for capital market regulations, and external debt to gross national income (GNI) (ExtDebt), is used as a measure of debt sustainability and external vulnerability. The institutional quality measure used is the composite Worldwide Governance Indicators (WGI), which is a simple average of the subcomponents Voice and Accountability, Political Stability and Absence of Violence, Government Effectiveness, Regulatory Quality, Rule of Law and Control of Corruption.

\section{Structural variables in $\boldsymbol{S}$}

Financial development is also affected by several structural variables such as income level, market size and demographics. Following Beck et al. (2008) and Barajas et al. (2013) we include the log of real GDP per capita (GDP pc), the log of population (Pop), and the log of the age dependency ratio (Age Dep ratio) to control for the respective income level, market size and demographics, respectively.

\section{Dollarization variables in $\boldsymbol{D}$}

The level of Inflation is already included in $\boldsymbol{P}$ and captures the currency substitution motivation for dollar investment. Following the portfolio approach, the dollar share of the minimum variance portfolio $(M V P)$ is included to take into account that resident investors may select the currency composition of their asset portfolio to minimize the effect of volatility of the exchange rate and inflation. ${ }^{9}$ The correlation between real GDP growth and the real exchange rate changes (REER $\mathrm{Cycl}$ ) is used to capture the real income effects of exchange rate volatility. The share of foreign banks among total banks (Foreign Banks) is included as credit dollarization is found to be higher and deposit dollarization is found to be lower in markets where foreign banks are present (Basso et al. 2011). The log of the nominal effective exchange rate (NEER) takes into account that dedollarization is generally associated with an exchange rate appreciation (as shown in GarciaEscribano and Sosa, 2011 and Catao and Terrones, 2016). Finally, a dummy variable for Eastern

\footnotetext{
${ }^{8}$ See e.g. Almarzoqi, Naceur and Kotak (2015), Barajas et al (2013), Court, Ozsoz and Rengifo (2012), De la Torre, Feyen and Ize (2013) and Trabelsi and Cherif (2017).

${ }^{9}$ The dollar share of the minimum-variance portfolio (MVP) is defined as:

$\operatorname{MVP}=[\operatorname{Var}(\pi)+\operatorname{Cov}(\pi, \mathrm{s})] /[\operatorname{Var}(\pi)+\operatorname{Var}(\mathrm{s})+2 \operatorname{Cov}(\pi, \mathrm{s})]$,

where $\pi$ denotes inflation and $\mathrm{s}$ is the change in the real exchange rate. The inflation and real effective exchange rate variances and the covariance are the respective values from the past five years.
} 
European transition economies (Transition) is included to control for the fact that dollarization generally is higher in transition economies than in the rest of the sample. In the robustness tests we also include imports to GDP (Imports) to control for trade openness, a measure for remittances to GDP (Remittances), and the short term (three month) nominal interest rate differential between the domestic economy and the US ( $i$ Diff).

\section{Estimation strategy}

The presence of fixed effects in equation (1) gives rise to an endogeneity issue if estimated with OLS, as the lagged dependent variable is correlated with the error term through the fixed effects. In panels where the time series dimension is relatively small like ours, this endogeneity creates biased coefficients, usually referred to as the Nickell bias (Nickell, 1981). To avoid the bias, we use the system and difference General Method of Moments (GMM) estimators.

The difference GMM estimator removes the fixed effect through differencing, and uses higher order lags of the endogenous regressors as instruments. However, if the dependent variable is highly persistent, the difference GMM estimator performs poorly as past changes in the variable contain little information about future changes. If that is the case, the system GMM estimator is considered a superior alternative. The system GMM exploits the fact that if a variable is highly persistent, past changes are more useful in predicting current levels than past levels are in predicting current changes (see Roodman, 2009). The system GMM estimator thereby uses the same moment conditions as the difference GMM, but in addition employs an additional set of level moment conditions. That is, the system GMM estimator includes also a level equation, where the levels are instrumented by their first differences.

As financial development, and especially financial depth, is a persistent phenomenon, the system GMM model is our preferred model. We also estimate difference GMM and fixed effects models to test the robustness of our results to the model specification (see Appendix II).

An additional benefit of the GMM estimators is that they allow us to relax the assumption of exogeneity of the regressors in the model. As dollarization, financial development and some of the macroeconomic, policy and institutional variables might be endogenously determined, we consider the impact of dollarization both when it and its determinants are assumed to be endogenous and predetermined. The log changes in GDP are considered endogenous to all dimensions of financial development, as there is reason to believe that output growth is endogenously affected by financial development. Inflation is also allowed to be endogenously determined by financial depth, as an increase in private credit to GDP could have simultaneous effects on the price level and on dollarization. The institutional, regulation and market structure policy variables are considered predetermined along with the banking crisis dummy, whereas the structural variables are assumed exogenous. To avoid simultaneity issues, the beginning of period values (i.e. one year lags) of the variables are used for all the predetermined and exogenous structural variables.

The system GMM estimator aims to deal with endogeneity between dollarization and financial development, and we also try to control for all the underlying reasons for dollarizing that might 
affect financial development as well. Bellemare et al. 2017 however argue that using lags to deal with reversed causality could lead to inconsistent and biased results if there are still some unobserved time varying sources of heterogeneity (although the GMM estimator does a better job than a model that relies only on lags for identification). The existence of some dynamic latent sources of heterogeneity could thus lead to biased results and increase the risk of making Type 1 errors, which is a pitfall of this empirical approach that we recognize.

Both the system and difference GMM estimators are designed for panels with a relatively short time dimension. As the number of instruments grows quadratically with the time dimension, instrument proliferation risks overfitting the endogenous variables (Roodman, 2009b). In order to reduce the instrument count, we "collapse" our instruments by combining the instruments through addition into smaller sets. Despite collapsing the instruments, we still have a fairly large instrument count when we allow dollarization along with its determinants to be endogenous. For that reason, we confirm that our results hold also when we use fewer instruments in the robustness section (see Appendix II).

\section{RESULTS}

In this section we present the results for estimating the impact of dollarization on financial development. We first focus on the impact of dollarization on financial depth (PrivCred), and in the latter part of this section we present the results on the impact of dollarization on financial access (Accounts) and financial efficiency (NetIntMarg). ${ }^{10}$

The results using our preferred system GMM methodology are presented below. ${ }^{11}$ For the baseline model for financial depth we report results both from estimations where dollarization and its determinants are considered predetermined and endogenous in the main text. For the rest of the analysis we only report the results from estimations where dollarization and its determinants are endogenous, and refer the reader to Appendix II for the predetermined cases.

\section{Financial Depth}

The baseline results measuring the impact of dollarization on financial sector depth, as measured by log of credit to GDP, are presented in Table 1. The results show that deposit dollarization has

\footnotetext{
${ }^{10}$ We have also explored an alternative approach based on financial possibility frontiers. Beck et al. (2008) posit that there is a constrained optimum of financial development in an economy, which builds on the notion that there is a maximal sustainable level of financial depth in an economy at any given time. This maximal sustainable level, referred to as the financial possibility frontier, depends on structural and long term policy variables that impact the access to financial services in an economy. We look at how dollarization affects the gap between the structural financial depth (as implied by the financial possibility frontier) and actual financial depth, and find only insignificant or non-robust results. These results are not presented for the sake of space but are available upon request.

${ }^{11}$ Results using difference GMM and the fixed effects (FE) models can be found in Table 4 in Appendix II. The difference GMM estimator generally performs poorly when the dependent variable is highly persistent (Roodman 2009b), so more weight should be given to the results from the system GMM estimations. Moreover, due to the Nickell bias in the FE model, the FE results should only be regarded as a check on the sign of the coefficients.
} 
a statistically significant negative impact on financial development (see columns 1 and 2). This result holds regardless of whether dollarization is considered endogenous or predetermined. The results suggest that a 1 percentage point increase in deposit dollarization reduces credit to GDP by around 0.4 percent in the short run, and 2-2.5 percent in the long run. Our results would therefore imply that, for the sample as a whole, the observed 5 percentage point reduction in dollarization since its peak has contributed to an increase in credit to GDP by about 10 percent in the past 15 years. ${ }^{12}$ For highly dollarized economies the gains from de-dollarization can be large -- cutting the level of dollarization by half (e.g. from about 90 percent to 45 percent) would potentially increase financial depth by close to 20 percent in the short run. Furthermore, the results suggest that in the long run halving dollarization could theoretically double financial depth in countries with near complete dollarization. The impact of credit dollarization is however much smaller and not statistically significant. $^{13}$

The lagged dependent variable is statistically significant in all models, thus validating our choice of a dynamic specification. The difference in magnitude of the estimated coefficients on dollarization between the models where dollarization and its determinants are considered predetermined versus endogenous is small. The results on financial depth are also robust to alternative specifications and estimation methods. For example, the same conclusion can also be drawn from a more parsimonious model with less instruments (Table 2 in Appendix II), from a model with only the significant control variables (Table 3 in Appendix II) and results produced using the difference GMM estimator (Table 4 in Appendix II). ${ }^{14}$

To confirm the suitability of the model and instruments, a number of diagnostic tests are performed. As can be seen from Table 1, the Arellano-Bond tests for order 2 serial correlation in the residuals, AB-AR(2), confirm that the models do not suffer from autocorrelation. ${ }^{15}$ The Hansen J-test of over-identifying restrictions furthermore confirms the joint validity of the instruments.

Deposit dollarization thus seems to have a significant and negative impact on financial deepening of the financial system, whereas credit dollarization does not. One possible explanation for these results is the hypothesis put forward by De Nicolo, Honohan and Ize (2005) that part of foreign currency deposits are exported rather than returned to the domestic economy in the form of private

\footnotetext{
12 Based on the long-run coefficient. Credit to GDP in our sample has increased by around 50 percent since 1996 while deposit dollarization has declined by around 5-8 percentage points since its peak in 2000 .

${ }^{13}$ Note that the sample for columns 3-4 is much smaller than for columns $1-2$. When the regressions in columns 1-2 are estimated with the same sample as in columns 3-4, we still find that deposit dollarization has a significantly negative impact on financial depth. Thus, the difference in results is not coming from the difference in sample but rather from the different measure of dollarization.

${ }^{14}$ In addition to deposit dollarization, we see that external debt, inflation, foreign banks, banking crises, the nominal effective exchange rate (NEER), low institutional quality and a high concentration of bank market power (3 Bank conc) have a negative, although not always very significant, impact on financial sector depth.

15 The null hypothesis for the Arrelano-Bond AR(p) test is no $\mathrm{p}$ order autocorrelation. Order one serial correlation is expected through the construction of the model. As we are unable to reject the null hypothesis of no second order autocorrelation, it justifies the use of second order lags as instruments for the lagged dependent variable.
} 
credit, which in turn leads to a shallower domestic financial sector. A simple correlation plot suggests a positive correlation between deposit dollarization and the share of assets that banks hold abroad (see Figure 9), suggesting that deposit dollarization may hamper financial depth as banks export part of the foreign currency deposits instead of extending new loans. ${ }^{16}$ Additionally, the existence of financial assets and liabilities in two or more currencies might create additional frictions and costs in the credit markets that inhibit further financial deepening.

\footnotetext{
${ }^{16}$ For some economies, this could also reflect a form of carry-trade, i.e. foreign investment in relatively high-yielding and stable
} foreign currency deposits in developing economies during periods of low global interest rates. 
Table 1. The Impact of Dollarization on Financial Debt

Private Credit /GDP

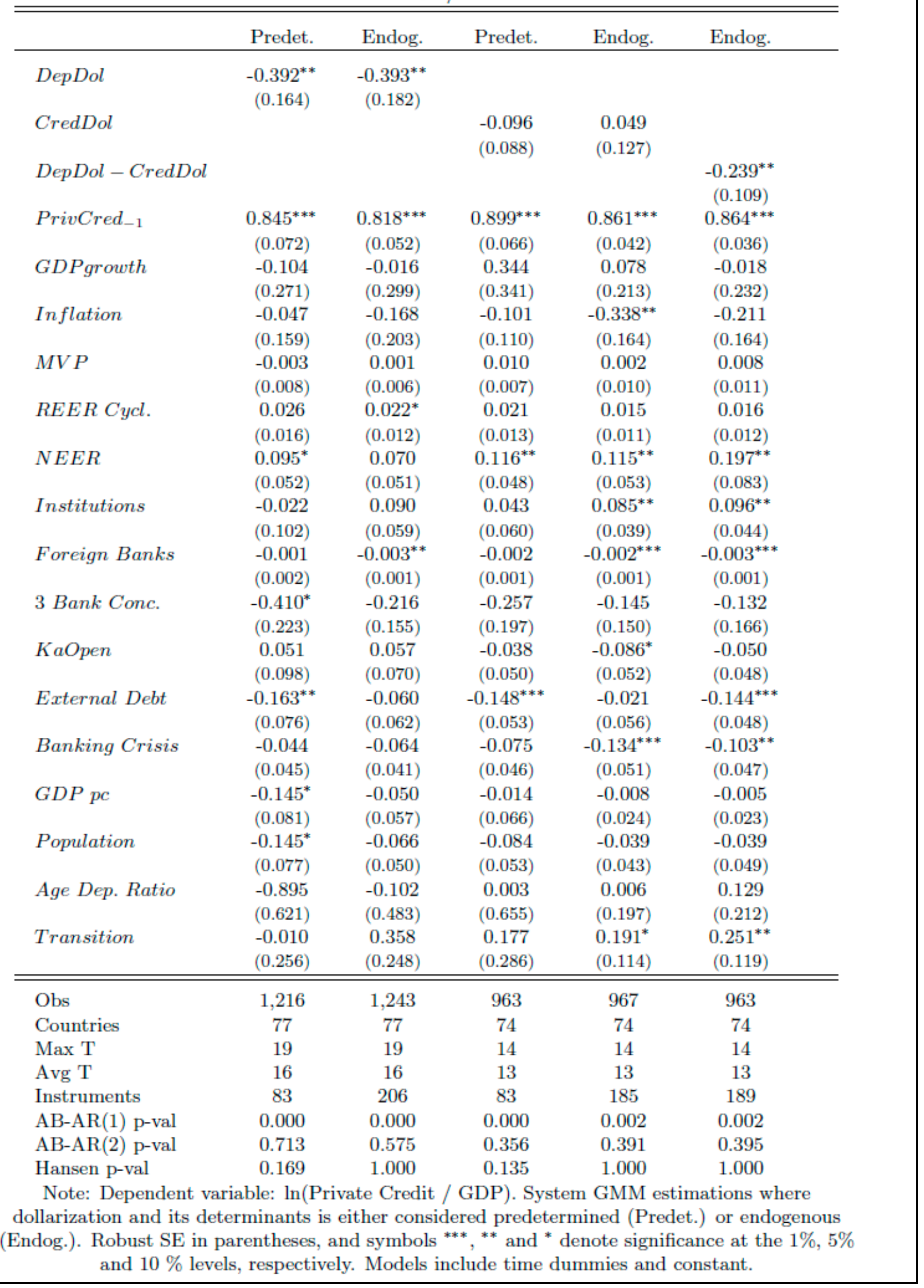


The baseline results shown in Table 1 suggest that there is a difference in how deposit and credit dollarization affects financial development. We explore these results further by examining first, the impact of the mismatch between deposit and credit dollarization on financial development and, second, the importance of high inflation episodes in explaining the impact of dollarization. ${ }^{17}$

If the negative impact of dollarization on financial development arises because the banking sector invests the foreign

Figure 9. Deposit Dollarization in Foreign Asset Ratios of Deposit Taking Banks

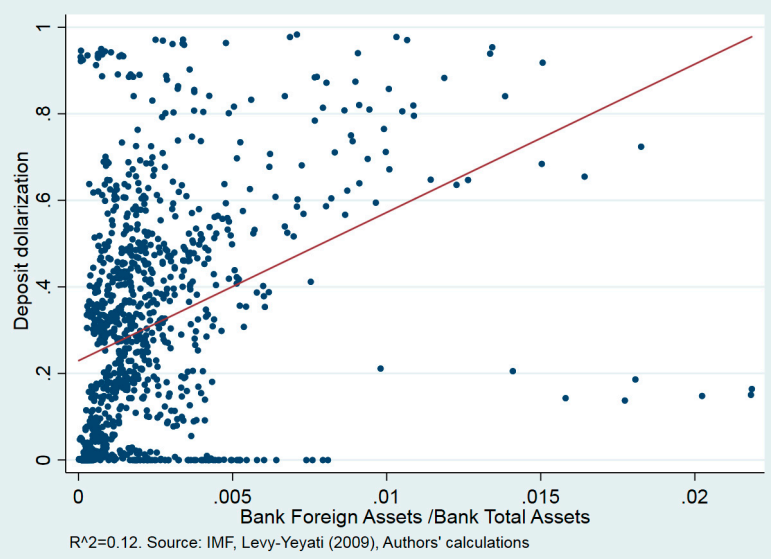
currency assets abroad rather than extending foreign currency loans to resident investors, the negative impact should be larger when the difference (or mismatch) between deposit and credit dollarization is larger. We therefore look at whether the aggregate difference in deposit and credit dollarization ratios (DepDol-CredDol) has an impact on financial depth. Re-estimating the system GMM estimations including this mismatch suggests that it does indeed have a negative effect on financial depth (see column 5, Table 1). ${ }^{18}$ These results are in line with the Honohan and Shi (2001) hypothesis that if banks receive more foreign currency deposits than they can return to the domestic financial market as foreign currency loans, they will invest the foreign currency deposits abroad. This result continues to hold if we use the difference between foreign currency deposits and credit scaled by GDP (not shown).

Second, the previous literature has found that the relationship between dollarization and financial development is somewhat different in high inflation economies compared to countries with stable price developments. De Nicolo, Honohan and Ize (2005) establish that deposit dollarization is associated with a deeper private financial sector in economies with high inflation. Court, Ozsoz and Rengifo (2012) find that dollarization reduces financial depth except in high-inflation economies. We extend our analysis to test whether financial development is supported by dollarization in countries with a history of high inflation. We add an interaction term between dollarization and a dummy variable that takes the value 1 if the country has experienced an annual inflation rate higher than 250 percent between 1980 and 1997, ${ }^{19}$ and zero otherwise. Alternatively, we add an interaction term of dollarization and the natural logarithm of the country's maximum

\footnotetext{
${ }^{17}$ We have also explored whether there are other sources of impact heterogeneity, such as income level, level of dollarization, financial market access, institutional quality, capital account openness, exchange rate regime or foreign bank presence. We do not find any robust results suggesting that the impact of dollarization is different across these characteristics.

${ }^{18}$ Here we present the results where the gap between deposit and credit dollarization is endogenous, but the same conclusions hold if we consider the gap predetermined.

${ }^{19}$ For the Eastern European transition economies this period is 1995-1998.
} 
historical inflation during $1980-1996 .{ }^{20}$ The results show some evidence that deposit dollarization has a less negative or even positive impact on financial depth in economies with a history of very high inflation (see Table 2). This suggests that deposit dollarization can be used by investors as a tool to circumvent some of the risks related to a history of macroeconomic instability. In some country cases, and in particular those hampered with high inflation and macroeconomic instability, dollarization could therefore facilitate financial deepening. This result also highlights the need to consider country specific circumstances in interpreting the average results obtained for the full sample. The results in Table 2 also confirm the previous finding that credit dollarization does not have a statistically significant impact on financial deepening.

\footnotetext{
${ }^{20} \mathrm{We}$ only consider historical inflation to reduce endogeneity concerns, but we reach the same conclusions when we consider the maximum inflation over the full sample period.
} 
Table 2. Dollarization and Financial Development in Countries with a History of High Inflation

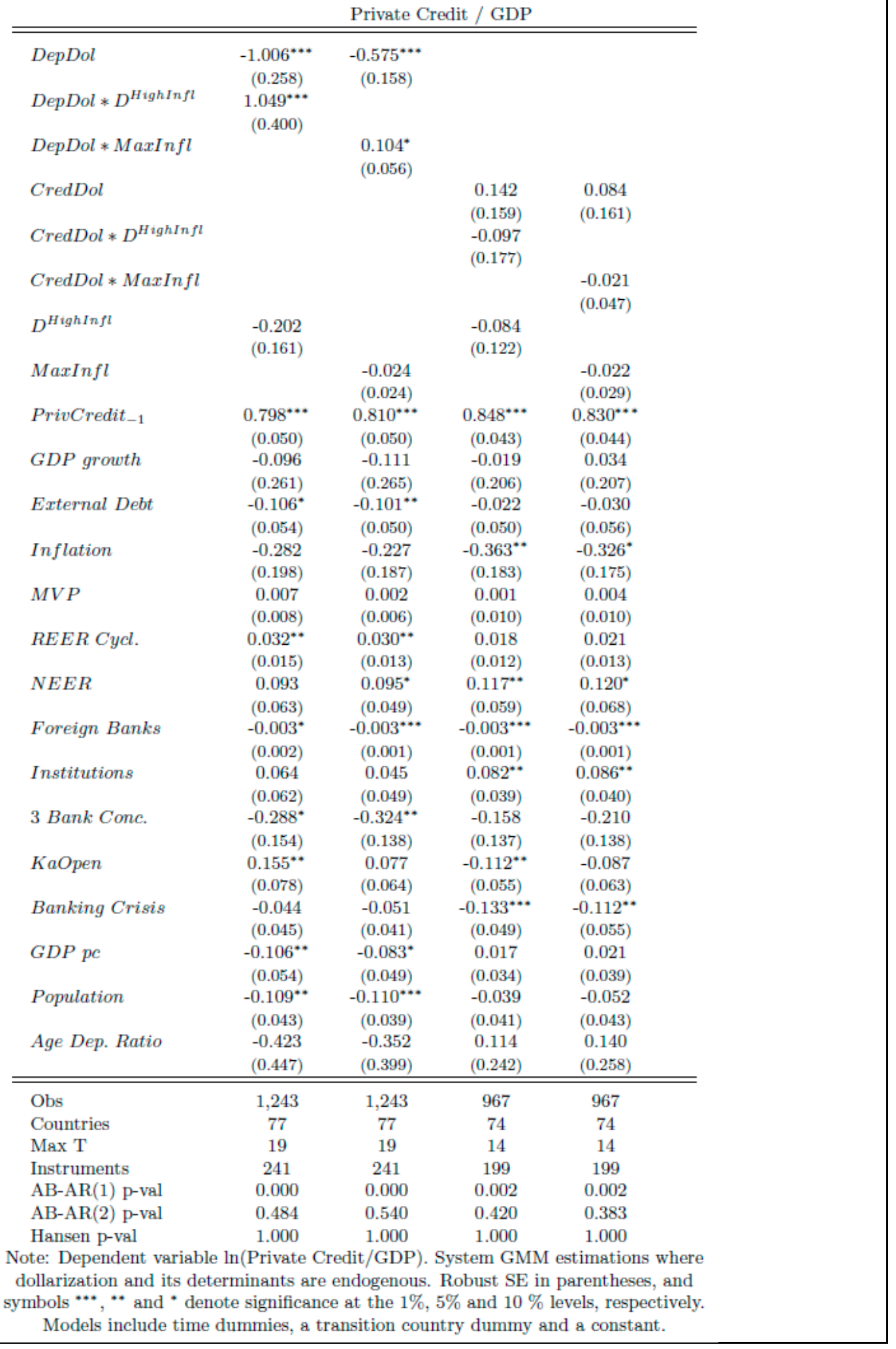


Financial Access and Efficiency

While financial depth is a useful summary indicator, it does not capture the multidimensional nature of financial development. We therefore look at the impact of dollarization on financial access, which is represented by the number of bank accounts per adult, and on financial efficiency, approximated by the aggregate net interest margin.

Our results show no evidence of a link between dollarization and financial access (columns 1 and 2 in Table 3). The results from the preferred system GMM estimation show that both deposit and credit dollarization have no significant impact on financial access. ${ }^{21}$

In contrast, there is some evidence that deposit dollarization increases the net interest margin charged by banks (see columns 3 and 4 in Table 3). As a higher net interest margin is a signal of lower financial sector efficiency, these results suggest that deposit dollarization may also have a negative influence on banking sector efficiency. As Honohan and Shi (2001) point out, this result may be related to the contraction in the supply of credit when banks shift their assets abroad (as there are strong economies of scale in banking). The higher spreads could also be related to higher concentration and monopoly power in the banking system in dollarized economies, as supported by the significance of the positive coefficient on the bank concentration variable (3 Bank Conc.) in our estimation. However, these results should be interpreted with care, as they rely on the model where dollarization is considered endogenous (thus including multiple instruments) and vary somewhat across alternative specifications and estimators. The negative impact on efficiency is statistically significant in the more parsimonious models (see Table 3 in Appendix II), but the magnitude of the coefficients varies depending on the model specification. When we reduce the number of instruments the coefficient on deposit dollarization is no longer significant (see Table 2 in Appendix II). In addition, few control variables are statistically significant, suggesting that the model may not be good at explaining drivers of financial efficiency. ${ }^{22}$

\footnotetext{
${ }^{21}$ When the same models are re-estimated using difference GMM (shown in Table 4 in Appendix II), we find that both deposit and credit dollarization have a statistically significant negative impact on financial access. However, as the difference GMM estimator tends to perform poorly when the dependent variable is highly persistent, we give more weight to the system GMM results.

${ }^{22}$ When we look at the impact of the spread between the deposit and lending rate instead of the Net Interest Margin we find similarly inconclusive results.
} 


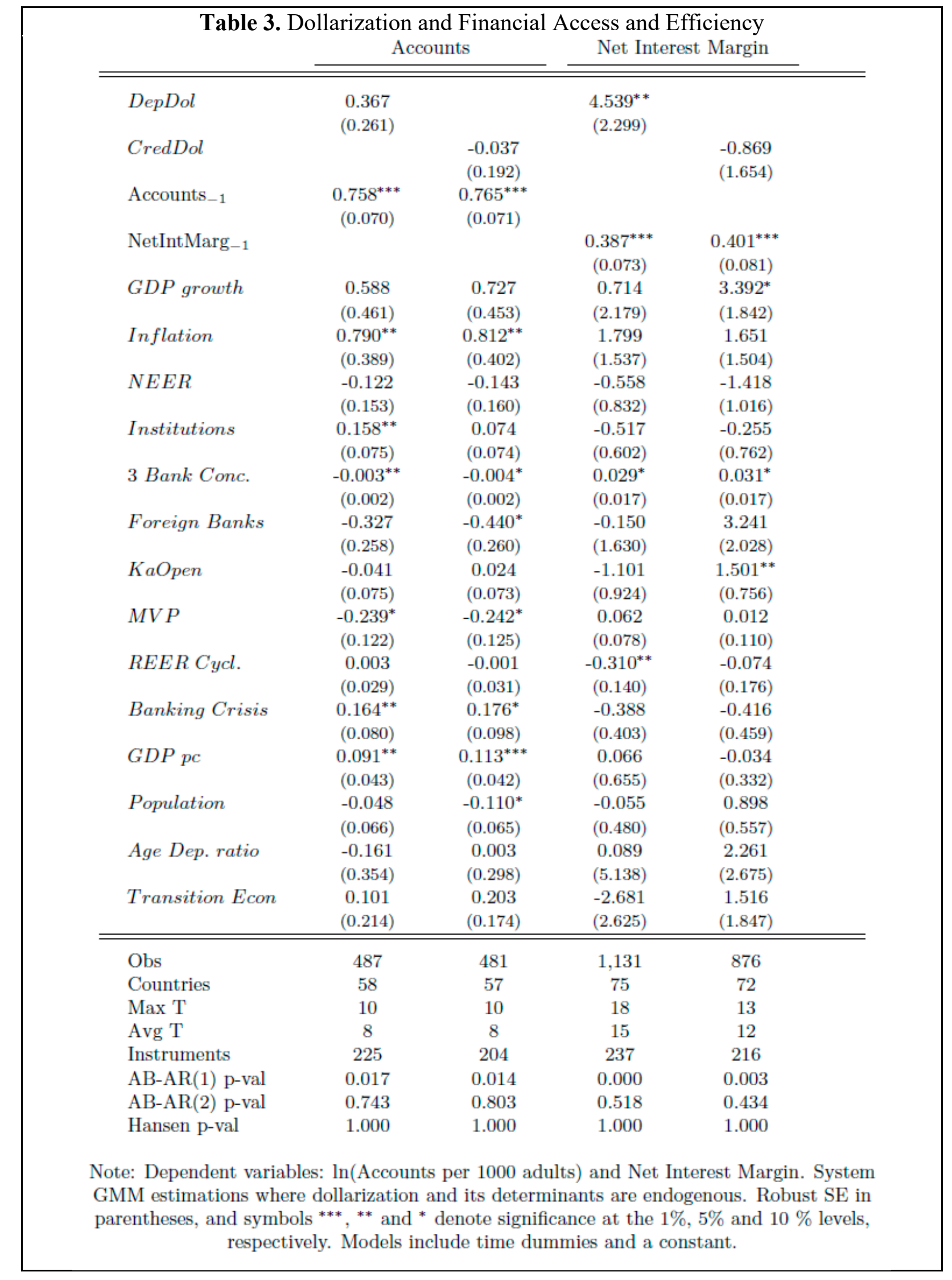




\section{Robustness}

Finally, we conduct a number of robustness checks to ensure that our conclusions still hold even if we reduce the number of instruments, use more parsimonious models, use alternative estimators, and if we exclude countries with low levels of dollarization. ${ }^{23}$ These results are presented in Appendix II. First, we confirm that our results are not driven by instrument proliferation. One drawback with the system (and difference) GMM is that the number of instruments grows rapidly in the time dimension, especially in the models where we allow dollarization and its determinants to be endogenous. The number of instruments is reduced if 1) we restrict dollarization and its determinants to be predetermined instead of endogenous (Appendix II, Table 1) or 2) allow only the lagged dependent variable, GDP growth, inflation and dollarization to be endogenous and restrict the dollarization determinants to be exogenous or predetermined (Table 2 in Appendix II). As can be seen from Appendix II, Table 2, reducing the instrument count does not change our main conclusions, and instead we find that, when we restrict the dollarization determinants and inflation to be predetermined rather than endogenous, the impact of deposit dollarization on financial depth is much larger and more negative.

Second, we confirm that our results hold even if we exclude the insignificant control variables from the models (Appendix II, Table 3). Third, we also find that the difference GMM estimations (Appendix II, Table 4) yield results similar to the preferred system GMM. The results from fixed effects (FE) estimations also support our general conclusions. ${ }^{24}$

Finally, we confirm that we reach the same conclusions when we exclude countries that have very low levels of dollarization, possibly owing to foreign exchange regulations (Appendix II, Table 5). In practice, we exclude all countries with either deposit or credit dollarization below 1 percent on average over the sample period, which leaves us with a sample of 63 countries.

\section{CONCLUSION}

Despite significant strides in financial development, financial dollarization remains common in developing economies. Consistent with past studies, our results using a large sample of emerging and developing economies show that financial dollarization can dampen financial development, and as a result, slow down economic development. In particular, our panel regression estimates show that deposit dollarization has a negative impact on financial deepening. We argue that this

\footnotetext{
${ }^{23}$ To confirm that we have properly controlled for the reasons why economies become dollarized in the first place, we have also created a proxy for dollarization which is by construction exogenous to the known or observed determinants of dollarization. We do this by estimating dollarization using a very rich set of dollarization determinants, and the resulting residuals can be seen as a proxy for the part of dollarization which is not related to the underlying reasons for dollarizing. The same conclusions as in the main analysis are reached when we use this by construction exogenous dollarization measure. These results are not reported but are available upon request.

${ }^{24}$ We have also estimated the model with dollarization and financial depth in first differences, and these results also indicate that a reduction in deposit dollarization has a positive effect on financial depth in the following year. These results are however not reported for the sake of space.
} 
negative impact may reflect the fact that a share of foreign currency deposits are transferred overseas rather than returned to the domestic economy as private credit. We also find that the negative impact of dollarization on financial development is dampened somewhat in countries with past experiences of high inflation. Therefore, while the results from the full sample suggest potentially large gains from de-dollarization on average, policy recommendations drawn from the results need to carefully consider country-specific circumstances. The results suggest that there may be country cases where dollarization helps mitigate the negative impact of high inflation and macroeconomic instability on financial development. Our estimates also provide some evidence of a negative relationship between dollarization and financial efficiency. It is possible that deposit dollarization contributes to shallower domestic credit markets and therefore limits opportunities to take advantage of economies of scale. We do not find evidence that dollarization has a statistically significant effect on financial inclusion in our data.

Our results are driven by deposit dollarization and we do not find consistent evidence that credit dollarization as such has an impact on financial development. Consistent with our results for deposit dollarization, however, we find that an aggregate level measure of mismatch (i.e. the difference between deposit and credit dollarization) is associated with lower levels of financial development. This is in line with evidence on currency mismatch as a source of financial sector instability. Further research, perhaps using data at a more granular (sectoral, firm or individual) level is needed to better understand how currency mismatch impacts financial development. We also note that while we have gone through significant effort to obtain robust empirical results, our system GMM estimation is only a partial solution to concerns about identification. Further research is therefore needed to explore strategies that could help better establish causality from dollarization to financial development. An alternative empirical approach would be to examine significant dedollarization events for evidence of their impact on financial development.

Overall, our results suggest that, in addition to concerns related to lower monetary policy effectiveness, limits to flexibility of fiscal policy and heightened financial stability risks, there are additional costs from dollarization related to lower financial depth and banking sector efficiency. The results therefore justify policy efforts to increase the use of the domestic currency in financial transactions. This is particularly the case for countries with a high degree of financial dollarization, where the gains from de-dollarization in terms of the development of local financial markets could be substantial. Studies of de-dollarization strategies suggest that dollarization is often a persistent phenomenon and that de-dollarization therefore requires sustained policy efforts on multiple fronts. Kokenyne et al (2010), Garcia-Escribano and Sosa (2011) and Catao and Terrones (2016) argue that credible macroeconomic stabilization policies to lower inflation and stabilize the exchange rate have been a key component of successful de-dollarization strategies in Europe and Latin America. Strengthening economic institutions, and particularly monetary policy frameworks that enhance the credibility of monetary policy in the face of external shocks, is a first step. Additional efforts are also needed to lower the incentives for financial institutions and economic agents to transact in foreign currencies. Prudential policies that have been successfully pursued include raising provisions for foreign currency loans, tighter capital requirements against open foreign exchange positions, differentiated reserve requirements and remuneration on foreign 
currency deposits, among others. Finally, the development of local currency financial markets can provide alternate vehicles for longer term investment and savings. 


\section{REFERENCES}

Almarzoqi, Raja, Sami Ben Naceur and Akshay Kotak, (2015): "What Matters for Financial Development and Stability?", IMF Working Paper 15/173.

Baliño, T., A. Bennett and E. Borensztein, (1999): "Monetary Policy in Dollarized Economies", IMF Occasional Papers No. 171. International Monetary Fund

Barajas, A., and Morales, R.A., (2003): "Dollarization of Liabilities: Beyond the Usual Suspects," IMF Working Paper, No. 03/11.

Barajas, A., Thorsten Beck, Era Dabla-Norris and Reza Yousefi (2013). "Too Cold, Too Hot, or Just Right? Assessing Financial Sector Development Across the Globe," IMF Working Paper, No. 13/81.

Basso, Henrique S, Calvo-Gonzalez, Oscar and Jurgilas, Marius, (2011): "Financial dollarization: The role of foreign-owned banks and interest rates," Journal of Banking \& Finance, Elsevier, vol. 35(4), pages 794-806, April

Beck, Thorsten, Erik Feyen, Alain Ize, and Florencia Moizeszowicz. (2008). "Benchmarking Financial Development." Policy Research Working Paper 4638, World Bank, Washington, DC

Beck, Thorsten and Hesse, Heiko, (2009): "Why Are Interest Spreads so High in Uganda?", Journal of Development Economics, 88, issue 2, p. 192-204

Bellemare, M. F., Masaki, T., and Pepinsky, T. B. (2017). "Lagged explanatory variables and the estimation of causal effect", The Journal of Politics, 79(3), 949-963.

Burnside, C., M. Eichenbaum and S. Rebelo (2001), "Hedging and Financial Fragility in Fixed Exchange Rate Regimes,” European Economic Review, Vol. 45, p. 1151-1193.

Caballero, R., and Krishnamurthy, A. (2003): "Excessive Dollar Debt: Financial Development and Underinsurance", The Journal of Finance, 58(2), 867-893.

Catão, Luis and Terrones, Marco E., (2016): "Financial De-Dollarization: A Global Perspective and the Peruvian Experience", IMF Working Paper No. 16/97.

Chinn, Menzie D. and Hiro Ito (2006): "What Matters for Financial Development? Capital Controls, Institutions, and Interactions," Journal of Development Economics, Volume 81, Issue 1, p. $163-192$.

Čihák, Martin; Demirgüç-Kunt, Aslı; Feyen, Erik; Levine, Ross. (2012), "Benchmarking Financial Systems around the World". Policy Research Working Paper; No. 6175. World Bank, Washington, DC

Claessens, S. and van Horen, N. (2014): "Foreign Banks: Trends and Impact", Journal of Money, Credit and Banking, 46: 295-326 
Claessens, S. and van Horen, N. (2015), "The Impact of the Global Financial Crisis on Banking Globalization", DNB WP No. 459

Court, Ozsoz and Rengifo (2012): "The Impact of Deposit Dollarization on Financial Deepening”, Emerging Markets Finance and Trade, Volume 48, 2012 - Issue 6

de la Torre, Augusto; Feyen, Erik; Ize, Alain. (2013): "Financial Development: Structure and Dynamics", Oxford University Press on behalf of the World Bank.

De Nicolo, P. Honohan, and A. Ize, (2005): "Dollarization of Bank Deposits: Causes and Consequences", Journal of Banking and Finance 29, pp. 1697-1727.

Duma, N. (2011): "Dollarization in Cambodia: Causes and Policy Implications". IMF Working Paper

Eichengreen, Barry, (2001): "What problems can dollarization solve?" Journal of Policy Modeling, 23, issue 3, p. 267-277

Feyen, E., and D. Sourrouille (2017). "FinStats 2017: A Ready-to-use Tool to Benchmark Financial Sectors Across Countries and Time", World Bank mimeo.

García-Escribano, M., Sosa, S., (2011): "What is Driving Financial De-dollarization in Latin America?", IMF Working Paper No 11/10

Gulde, Anne Marie, David S. Hoelscher, lain Ize, Dewitt D Marston and Gianni De Nicolo, (2004). "Financial Stability in Dollarized Economies," IMF Occasional Papers 230, International Monetary Fund.

Hausmann, Ricardo (1999): "Should there be five currencies or one hundred and five?" Foreign Policy, 116, 65-79.

Hausmann, Ricardo, Panizza, Ugo and Stein, Ernesto, (2001): "Why Do Countries Float the Way They Float?”, Journal of Development Economics, 66, issue 2, p. 387-414,

Honohan, Patrick; Shi, Anqing. (2001): "Deposit Dollarization and the Financial Sector in Emerging Economies”, Policy Research Working Paper; No. 2748. World Bank, Washington, DC

International Monetary Fund, World Economic Outlook Database (2017)

International Monetary Fund, International Financial Statistics (IFS) (2017)

Ize, A., and E. Levy Yeyati (2003): "Financial Dollarization", Journal of International Economics 59, no 2:323-347

Ize, A., and E. Levy Yeyati (2005): "Financial De-Dollarization: Is it for Real?", IMF Working Paper No. 05/187.

Jeanne, Olivier. (2000): "Foreign Currency Debt and the Global Financial Architecture". European Economic Review 44, nos. 4-6: 719-27. 
Jeanne, Olivier D (2003). "Why Do Emerging Economies Borrow in Foreign Currency?", IMF Working Papers 03/177, International Monetary Fund.

Kaufmann, Daniel, Aart Kraay and Massimo Mastruzzi (2010): "The Worldwide Governance Indicators: A Summary of Methodology, Data and Analytical Issues", World Bank Policy Research, Working Paper No. 5430.

Kokenyne, Annamaria, Jeremy Levy and Romain Veyrune (2010), "Dedollarization", IMF Working Paper, No. 10/188.

Laeven, L. and Valencia, F. (2013). "Systemic Banking Crises Database: An Update", IMF $\mathrm{WP} / 12 / 163$

Levine, R. (2005): "Finance and Growth: Theory and Evidence", in Aghion, P. and Durlauf, S. (eds.): Handbook of Economic Growth, Elsevier.

Levy Yeyati, Eduardo (2006): "Financial Dollarization: Evaluating the Consequences", Economic Policy, Vol. 21, No. 45, pp. 61-118, January 2006.

Mwase, Nkunde and Francis Y. Kumah (2015): "Revisiting the Concept of Dollarization: The Global Financial Crisis and Dollarization in Low-Income Countries", IMF Working Paper No. $15 / 12$

Nickell, S. (1981): "Biases in Dynamic Models with Fixed Effects”, Econometrica 49(6).

Reinhart, Carmen M., Kenneth S. Rogoff and Miguel A. Savastano, (2014). "Addicted to Dollars," Annals of Economics and Finance, Society for AEF, vol. 15(1), pages 1-50, May

Roodman, D. (2009a): "How To Do xtabond2: An Introduction To Difference and System GMM in Stata", Stata Journal vol. 9(1), pp. 86-136, March.

Roodman, D. (2009b): "A Note on the Theme of Too Many Instruments," Oxford Bulletin of Economics and Statistics, Vol. 71 No. 1, p. 135-158.

Sahay, R. et al., (2015): "Rethinking Financial Deepening: Stability and Growth in Emerging Markets", IMF Staff Discussion Note 15/08.

Savastano, Miguel A. (1996), "Dollarization in Latin America: Recent Evidence and Some Policy Issues," in P. Mizen and E. Pentecost (eds.), The Macroeconomics of International Currencies, (Brookfield Vt., Edward Elgar).

Stiglitz, Joseph E., and Andrew Weiss. "Credit Rationing in Markets with Imperfect Information.” The American Economic Review, vol. 71, no. 3, 1981, pp. 393-410.

Trabelsi, Mohamed and Cherif, Mondher, (2017): "Capital Account Liberalization and Financial Deepening: Does the Private Sector Matter?, The Quarterly Review of Economics and Finance, 64, issue C, p. 141-151. World Bank, International Debt Statistics (2017) 


\section{APPENDIX I: DATA}

The dataset contains annual data for a sample of 77 emerging market and developing countries over the period 1996-2015. The sample is limited by data availability, and the countries included in the sample have dollarization levels ranging between 0 and 98 percent (for both credit and deposit dollarization). As we are interested in the impact of partial dollarization on financial development, fully dollarized countries are excluded from the study along with countries with currencies whose currencies are pegged to the USD (i.e. show close to zero exchange rate volatility) over the sample period. The data panel is unbalanced, as not all of the series are available at the starting date for all the countries. The Eastern European transition economies are included in the sample from 1997 onwards.

\section{Country coverage}

The countries included in the sample are Albania, Algeria, Angola, Argentina, Armenia, Azerbaijan, Bangladesh, Belarus, Benin, Bolivia, Bosnia and Herzegovina, Brazil, Bulgaria, Burundi, Cambodia, Chile, China, Colombia, Costa Rica, Croatia, Dominican Republic, Egypt, Georgia, Ghana, Guatemala, Haiti, Honduras, Hungary, India, Indonesia, Israel, Jamaica, Kazakhstan, Kenya, Republic of Korea, Kuwait, Kyrgyz Republic, FYR Macedonia, Madagascar, Malawi, Malaysia, Mauritius, Mexico, Moldova, Mongolia, Morocco, Mozambique, Namibia, Nepal, Nicaragua, Nigeria, Pakistan, Paraguay, Peru, Philippines, Poland, Romania, Russia, Rwanda, Senegal, South Africa, Sri Lanka, Sudan, Swaziland, Tanzania, Thailand, Togo, Trinidad and Tobago, Tunisia, Turkey, Uganda, Ukraine, Uruguay, Venezuela, Vietnam, Yemen and Zambia.

\section{Dollarization}

Deposit dollarization $(\mathrm{DepDol})$ is defined as total foreign currency deposits in broad money over total broad money deposits. Credit dollarization $(\mathrm{CredDol})$ is defined as foreign currency loans over total loans. The dollarization data is collected from a number of sources. Deposit and credit dollarization data from 2001 onward is obtained from the IMF's Standardized Report Form (SRF) for 70 of the countries in our sample. Deposit dollarization data for the time prior to 2001 is supplemented by data from Levy Yeyati's (2009) dollarization database. ${ }^{1}$ As not all countries report their foreign currency deposits and loans via the SRF, the missing dollarization data for these countries were supplemented by data from IMF staff reports and Levy Yeyati (2009). The deposit dollarization data is thus available from 1996 onward for some of the countries, whereas the credit dollarization data starts only in 2001.

\footnotetext{
${ }^{1}$ For the countries where the Levy-Yeyati and IMF deposit dollarization data for the overlapping period of 2001-2009 is different, we used the backward growth rates of the dollarization ratios to extrapolate the SRF deposit dollarization data series.
} 
Financial development

The financial development data are retrieved from the Global Financial Development Database (GFDD) compiled in Cihak, Demirguc-Kunt, Feyen and Levine (2012). Financial depth (PrivCred) is defined as Private credit by deposit money banks and other financial institutions to GDP (percent). This data is collected from the International Financial Statistics (IFS). Financial access (Accounts) is proxied by the number of bank accounts with commercial banks per 1,000 adults, originally published in the IMF's Financial Access Survey (FAS). Financial efficiency (NetIntMarg), represented by bank net interest margin (percent), is defined as the accounting value of bank's net interest revenue as a share of its average interest-bearing (total earning) assets (originally sourced from Bankscope, Bureau van Dijk (BvD)). Another measure of efficiency is the bank lending-deposit spread, defined as the difference between lending rate and deposit rate, originally published in the IMF's International Financial Statistics (IFS).

Data for GDP per capita in 2010 USD (GDP pc), Population (Population), Population density (PopDens) proxied by millions of people per square kilometer, Age dependency ratio (percent) (AgeDepRatio) and dummies for Eastern European transition country (Transition), fuel exporter, offshore financial center status are collected from the FinStats database by Feyen and Sourroille (2017).

\section{Control and additional variables}

The control variables are collected from a number of sources. The change in the Consumer Price index (CPI) from IFS is used as a measure of inflation (Inflation). Nominal and real effective exchange rates based on CPI (NEER and REER) are collected from the World Economic Outlook database. The dollar share of the minimum-variance portfolio (MVP) is defined as:

$\operatorname{MVP}=[\operatorname{Var}(\pi)+\operatorname{Cov}(\pi, s)] /[\operatorname{Var}(\pi)+\operatorname{Var}(\mathrm{s})+2 \operatorname{Cov}(\pi, \mathrm{s})]$,

where $\pi$ denotes inflation and $s$ is the change in the real exchange rate. The inflation and real effective exchange rate variances and the covariance are the respective values from the past five years. (This expression could also be simplified to $\mathrm{MVP}=\operatorname{Var}(\pi) / \operatorname{Cov}(\pi, e)$, where $e$ denotes the nominal rate of devaluation.)

The Three Bank Concentration ratio (3BankConc) from GFDD is defined as the assets of the three largest commercial banks as a share of total commercial banking assets in the country. The share of foreign banks among total banks (ForeignBanks) is defined by Claessens and Horen (2015) as the share of the number of foreign owned banks to the number of the total banks in a country. A bank is defined as foreign if 50 percent or more of its shares are owned by foreigners. The banking crisis variable (BankingCrisis), constructed by Laeven and Valencia (2013), is a dummy variable taking on value one if the country is in a systemic banking crisis, and zero otherwise. Chinn and Ito's (2006) measure of capital account openness (KaOpen) is used as a de jure measure of financial openness. Remittance inflows to GDP, reported in the GFDD, measures current transfers by migrant workers as well as wages and salaries earned by nonresident workers, as a fraction of 
GDP. Trade openness (Imports) is proxied by the ratio of imports to GDP (and we also use exports to GDP for robustness), with the data taken from WDI. The interest rate difference, (iDiff), is the three month nominal deposit interest rate difference between the domestic economy and the US, collected from IFS. External debt per GNI (ExtDebt) is collected from the World Bank's International Debt Statistics and Quarterly External Debt Statistics. ${ }^{2}$

There are several different measures of institutional quality available that measure somewhat different institutional dimensions. In this study we use the composite Worldwide Governance Indicators (WGI) from Kaufmann, Kraay and Mastruzzi (2010) as our measure of institutional quality. The composite WGI indicator is the simple average of the six different measures of institutional quality; Voice and Accountability, Political Stability and Absence of Violence, Government Effectiveness, Regulatory Quality, Rule of Law and Control of Corruption.

Bank Foreign Assets consists of foreign portfolio investment and other foreign assets by deposittaking corporations, except the central bank, as reported in the IMF's Balance of Payment statistics, International Investment Position. Bank Total Assets is from the GFDD and is defined as total assets held by deposit money banks.

\footnotetext{
${ }^{2}$ The external debt data for Kuwait, Namibia and Trinidad and Tobago are collected from IMF staff reports, and the external debt to GNI data for Trinidad and Tobago only includes external government debt.
} 


\begin{tabular}{|lrrrrr|}
\hline & Table 1. Summary Statistics & & & \\
& Mean & Std. Dev & Min & Max & Obs \\
\hline Deposit Dollarization & 0.291 & 0.245 & 0 & 0.984 & 1427 \\
Credit Dollarization & 0.252 & 0.240 & 0 & 0.982 & 1070 \\
Private Credit to GDP & 34.82 & 28.09 & 1.61 & 165.7 & 1427 \\
Net Interest Margin & 5.755 & 2.931 & 0.17 & 25.49 & 1406 \\
Accounts per 1000 adults & 942.4 & 915.7 & 2.39 & 5342 & 605 \\
GDP p.c., USD & 4739.1 & 6266.4 & 160.3 & 49015.9 & 1427 \\
Inflation & 0.134 & 1.146 & -0.09 & 41.45 & 1425 \\
Foreign Banks (\%) & 38.84 & 25.66 & 0 & 100 & 1357 \\
3 Bank concentration ratio & 0.626 & 0.189 & 0.146 & 1 & 1398 \\
NEER & 405.7 & 8200 & 33.2 & 304944 & 1427 \\
KaOpen & 0.476 & 0.330 & 0 & 1 & 1426 \\
WGI & -0.324 & 0.567 & -1.67 & 1.25 & 1427 \\
REER Cyclicality & 0.104 & 0.544 & -0.99 & 1.00 & 1383 \\
External Debt/GNI & 0.502 & 0.335 & 0.03 & 2.26 & 1394 \\
MVP & 0.045 & 0.934 & -2.69 & 9.59 & 1338 \\
Population (mil.) & 51.0 & 157.7 & 0.47 & 1371.2 & 1427 \\
Age Dependency Ratio & 4.101 & 0.288 & 3.47 & 4.73 & 1427 \\
Transition Economy dummy & 0.222 & 0.416 & 0 & 1 & 1427 \\
Banking Crisis Dummy & 0.056 & 0.229 & 0 & 1 & 1423 \\
& & & & & \\
\hline
\end{tabular}




\section{APPENDIX II: ADDITIONAL RESULTS}

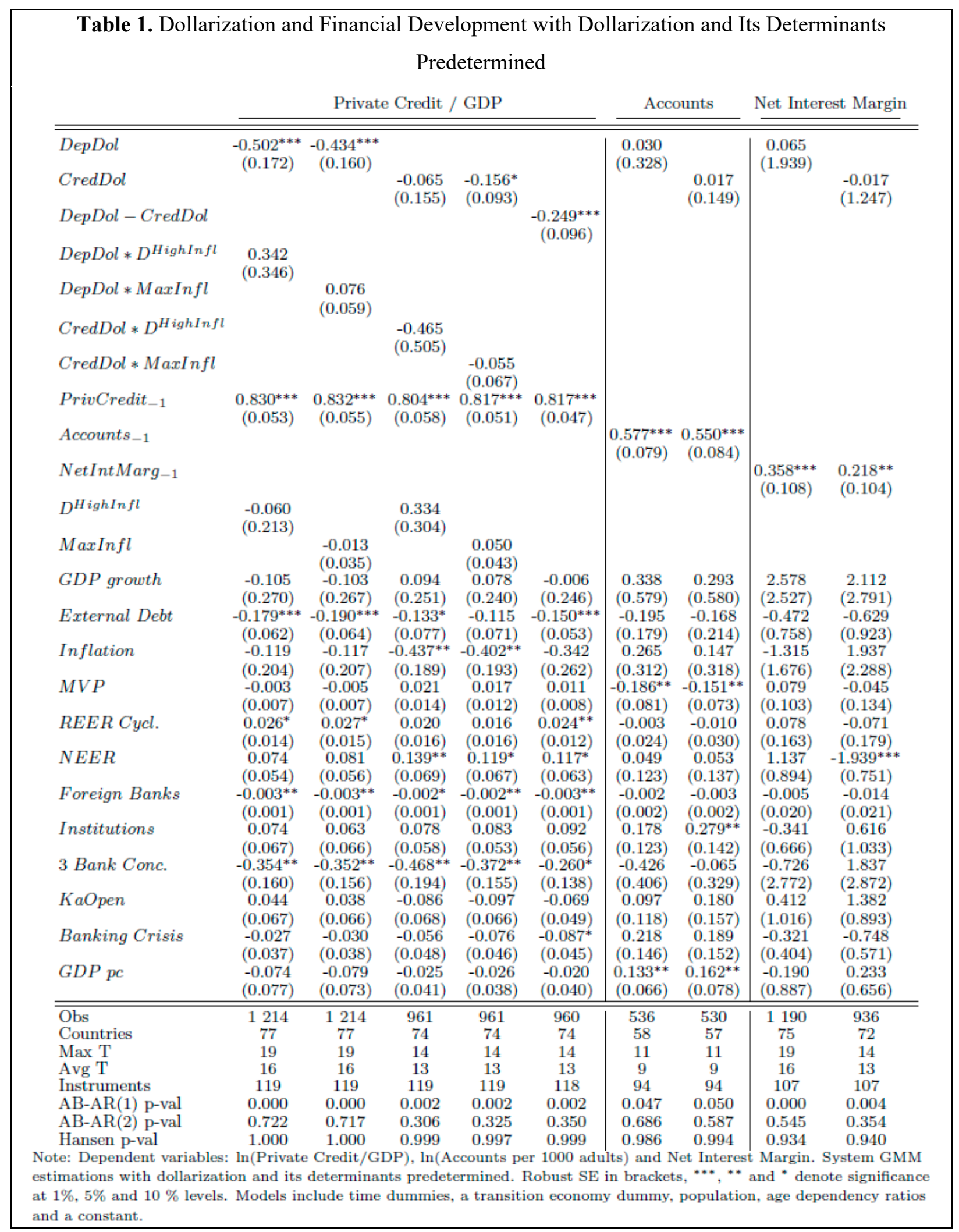


Table 2. Dollarization and Financial Development Relationship Estimated with Fewer Instruments

\begin{tabular}{|c|c|c|c|c|c|c|}
\hline \multirow{2}{*}{$\overline{\text { DepDol }}$} & \multicolumn{2}{|c|}{ Private Credit / GDP } & \multicolumn{2}{|c|}{ Accounts } & \multicolumn{2}{|c|}{ Net Interest Margin } \\
\hline & $\begin{array}{c}-0.604^{* *} \\
(0.258)\end{array}$ & & $\begin{array}{l}-0.818 \\
(0.818)\end{array}$ & & $\begin{array}{c}6.336 \\
(9.368)\end{array}$ & \\
\hline CredDol & & $\begin{array}{l}-0.150 \\
(0.204)\end{array}$ & & $\begin{array}{l}-0.686 \\
(0.500)\end{array}$ & & $\begin{array}{c}1.520 \\
(2.895)\end{array}$ \\
\hline PrivCredit $_{-1}$ & $\begin{array}{c}0.729^{* * *} \\
(0.101)\end{array}$ & $\begin{array}{c}0.700^{* * *} \\
(0.082)\end{array}$ & & & & \\
\hline Accounts $_{-1}$ & & & $\begin{array}{c}0.627^{* * *} \\
(0.120)\end{array}$ & $\begin{array}{c}0.583^{* * *} \\
(0.113)\end{array}$ & & \\
\hline NetIntMarg -1 & & & & & $\begin{array}{l}0.288^{*} \\
(0.147)\end{array}$ & $\begin{array}{c}0.173 \\
(0.131)\end{array}$ \\
\hline GDP growth & $\begin{array}{l}-0.217 \\
(0.401)\end{array}$ & $\begin{array}{l}-0.134 \\
(0.314)\end{array}$ & $\begin{array}{l}-0.068 \\
(0.585)\end{array}$ & $\begin{array}{c}0.041 \\
(0.572)\end{array}$ & $\begin{array}{l}-0.498 \\
(1.954)\end{array}$ & $\begin{array}{c}1.530 \\
(1.667)\end{array}$ \\
\hline External Debt & $\begin{array}{c}-0.237^{* *} \\
(0.098)\end{array}$ & $\begin{array}{l}-0.121 \\
(0.081)\end{array}$ & $\begin{array}{l}-0.047 \\
(0.244)\end{array}$ & $\begin{array}{l}-0.040 \\
(0.247)\end{array}$ & $\begin{array}{l}-0.498 \\
(1.954)\end{array}$ & $\begin{array}{c}1.530 \\
(1.667)\end{array}$ \\
\hline Inflation & $\begin{array}{c}0.020 \\
(0.129)\end{array}$ & $\begin{array}{l}-0.226 \\
(0.145)\end{array}$ & $\begin{array}{l}0.823^{*} \\
(0.450)\end{array}$ & $\begin{array}{c}0.611 \\
(0.381)\end{array}$ & $\begin{array}{l}-2.040 \\
(3.557)\end{array}$ & $\begin{array}{l}-0.289 \\
(3.682)\end{array}$ \\
\hline$M V P$ & $\begin{array}{c}0.011 \\
(0.014)\end{array}$ & $\begin{array}{c}0.007 \\
(0.014)\end{array}$ & $\begin{array}{c}-0.322^{* * * *} \\
(0.122)\end{array}$ & $\begin{array}{r}-0.235^{*} \\
(0.126)\end{array}$ & $\begin{array}{l}0.219^{*} \\
(0.124)\end{array}$ & $\begin{array}{c}0.139 \\
(0.276)\end{array}$ \\
\hline REER Cycl. & $\begin{array}{c}0.020 \\
(0.037)\end{array}$ & $\begin{array}{c}0.037 \\
(0.028)\end{array}$ & $\begin{array}{l}-0.034 \\
(0.034)\end{array}$ & $\begin{array}{l}-0.032 \\
(0.041)\end{array}$ & $\begin{array}{l}0.675^{*} \\
(0.371)\end{array}$ & $\begin{array}{l}-0.123 \\
(0.327)\end{array}$ \\
\hline$N E E R$ & $\begin{array}{l}-0.028 \\
(0.110)\end{array}$ & $\begin{array}{c}0.119 \\
(0.098)\end{array}$ & $\begin{array}{c}-0.593^{*} \\
(0.320)\end{array}$ & $\begin{array}{r}-0.568^{*} \\
(0.293)\end{array}$ & $\begin{array}{l}-0.198 \\
(2.877)\end{array}$ & $\begin{array}{l}-1.441 \\
(2.151)\end{array}$ \\
\hline Foreign Banks & $\begin{array}{c}0.004 \\
(0.005)\end{array}$ & $\begin{array}{c}0.009^{* *} \\
(0.004)\end{array}$ & $\begin{array}{l}-0.002 \\
(0.004)\end{array}$ & $\begin{array}{c}0.001 \\
(0.005)\end{array}$ & $\begin{array}{l}-0.035 \\
(0.046)\end{array}$ & $\begin{array}{c}-0.063^{* *} \\
(0.031)\end{array}$ \\
\hline Institutions & $\begin{array}{c}0.371 \\
(0.283)\end{array}$ & $\begin{array}{c}0.015 \\
(0.162)\end{array}$ & $\begin{array}{c}0.319 \\
(0.380)\end{array}$ & $\begin{array}{c}0.282 \\
(0.335)\end{array}$ & $\begin{array}{l}-2.726 \\
(2.254)\end{array}$ & $\begin{array}{l}-1.214 \\
(2.155)\end{array}$ \\
\hline 3 Bank Conc. & $\begin{array}{c}-0.841^{* * *} \\
(0.256)\end{array}$ & $\begin{array}{c}-0.493^{*} \\
(0.266)\end{array}$ & $\begin{array}{l}-0.528 \\
(0.427)\end{array}$ & $\begin{array}{l}-0.578 \\
(0.503)\end{array}$ & $\begin{array}{c}4.123 \\
(4.493)\end{array}$ & $\begin{array}{c}2.367 \\
(2.948)\end{array}$ \\
\hline KaOpen & $\begin{array}{c}0.091 \\
(0.231)\end{array}$ & $\begin{array}{l}-0.005 \\
(0.157)\end{array}$ & $\begin{array}{c}0.081 \\
(0.247)\end{array}$ & $\begin{array}{c}0.441 \\
(0.291)\end{array}$ & $\begin{array}{l}-4.544 \\
(3.808)\end{array}$ & $\begin{array}{l}-0.287 \\
(2.768)\end{array}$ \\
\hline Banking Crisis & $\begin{array}{l}-0.072 \\
(0.092)\end{array}$ & $\begin{array}{c}-0.210^{* *} \\
(0.103)\end{array}$ & $\begin{array}{c}0.349 \\
(0.225)\end{array}$ & $\begin{array}{c}0.400 \\
(0.262)\end{array}$ & $\begin{array}{l}-0.568 \\
(1.588)\end{array}$ & $\begin{array}{l}-0.454 \\
(0.922)\end{array}$ \\
\hline$G D P p c$ & $\begin{array}{l}-0.347 \\
(0.230)\end{array}$ & $\begin{array}{l}-0.117 \\
(0.138)\end{array}$ & $\begin{array}{l}-0.014 \\
(0.228)\end{array}$ & $\begin{array}{l}-0.023 \\
(0.265)\end{array}$ & $\begin{array}{c}7.373^{* *} \\
(3.756)\end{array}$ & $\begin{array}{c}1.381 \\
(2.209)\end{array}$ \\
\hline Population & $\begin{array}{l}-0.148 \\
(0.137)\end{array}$ & $\begin{array}{c}0.090 \\
(0.148)\end{array}$ & $\begin{array}{c}-0.358^{*} \\
(0.198)\end{array}$ & $\begin{array}{l}-0.228 \\
(0.139)\end{array}$ & $\begin{array}{l}-4.164 \\
(3.378)\end{array}$ & $\begin{array}{l}-1.761 \\
(2.511)\end{array}$ \\
\hline Age Dep. Ratio & $\begin{array}{l}-0.406 \\
(1.103)\end{array}$ & $\begin{array}{c}-0.669^{*} \\
(0.377)\end{array}$ & $\begin{array}{l}-0.396 \\
(0.824)\end{array}$ & $\begin{array}{l}-0.192 \\
(0.863)\end{array}$ & $\begin{array}{c}8.377 \\
(28.730)\end{array}$ & $\begin{array}{c}5.599 \\
(8.447)\end{array}$ \\
\hline Transition & $\begin{array}{c}0.106 \\
(0.367) \\
\end{array}$ & $\begin{array}{l}-0.109 \\
(0.257) \\
\end{array}$ & $\begin{array}{l}-0.338 \\
(0.654) \\
\end{array}$ & $\begin{array}{c}0.101 \\
(0.569) \\
\end{array}$ & $\begin{array}{l}-11.681 \\
(18.285) \\
\end{array}$ & $\begin{array}{l}-0.546 \\
(7.203) \\
\end{array}$ \\
\hline Obs & 1,239 & 966 & 536 & 530 & 1,194 & 940 \\
\hline Countries & 77 & 74 & 58 & 57 & 75 & 72 \\
\hline $\operatorname{Max} T$ & 19 & 14 & 11 & 11 & 19 & 14 \\
\hline Avg T & 16 & 13 & 9 & 9 & 16 & 13 \\
\hline Instruments & 107 & 107 & 111 & 111 & 97 & 97 \\
\hline $\mathrm{AB}-\mathrm{AR}(1) \mathrm{p}-\mathrm{val}$ & 0.000 & 0.001 & 0.035 & 0.049 & 0.000 & 0.003 \\
\hline $\mathrm{AB}-\mathrm{AR}(2) \mathrm{p}-\mathrm{val}$ & 0.359 & 0.209 & 0.477 & 0.769 & 0.477 & 0.769 \\
\hline Hansen p-val & 0.991 & 0.972 & 1.000 & 1.000 & 0.988 & 0.652 \\
\hline $\begin{array}{l}\text { Note: Dependent v } \\
\text { Margin. System G1 } \\
\text { dollarization are as } \\
\text { significance at the } 1\end{array}$ & $\begin{array}{l}\text { ables: } \ln (\mathrm{P} \\
1 \text { estimatior } \\
\text { med endoge } \\
5 \% \text { and } 10\end{array}$ & $\begin{array}{l}\text { ate Credit/ } \\
\text { where the } \\
\text { us. Robust } \\
\text { levels, resp }\end{array}$ & $\begin{array}{l}\mathrm{P}), \ln (\mathrm{Acc} \\
\text { ged depend } \\
\mathrm{E} \text { in parent } \\
\text { tively. Mod }\end{array}$ & $\begin{array}{l}\text { nts per } 10 \\
\text { variable, } \\
\text { es, and sy } \\
\text { include ti }\end{array}$ & $\begin{array}{l}\text { dults) an } \\
\mathrm{P} \text { growth } \\
\text { ols }{ }^{* * *},{ }^{* *} \\
\text { dummies }\end{array}$ & $\begin{array}{l}\text { et Intere } \\
\text { lation al } \\
{ }^{*} \text { deno } \\
\text { a const: }\end{array}$ \\
\hline
\end{tabular}




\begin{tabular}{|c|c|c|c|c|c|c|}
\hline \multicolumn{3}{|c|}{$\begin{array}{l}\text { Table 3. Dollarization and Financial } \\
\qquad \begin{array}{c}\text { Private Credit / GDP } \\
\end{array} \\
\end{array}$} & \multicolumn{2}{|c|}{ Accounts } & \multicolumn{2}{|c|}{ Net Interest Margin } \\
\hline DepDol & $\begin{array}{c}-0.451^{* *} \\
(0.183)\end{array}$ & & $\begin{array}{l}-0.444 \\
(0.433)\end{array}$ & & $\begin{array}{c}5.496 * * * \\
(1.330)\end{array}$ & \\
\hline CredDol & & $\begin{array}{c}0.194 \\
(0.122)\end{array}$ & & $\begin{array}{c}-0.804^{* *} \\
(0.400)\end{array}$ & & $\begin{array}{c}0.632 \\
(1.420)\end{array}$ \\
\hline PrivCredit $_{-1}$ & $\begin{array}{c}0.896^{* * *} \\
(0.040)\end{array}$ & $\begin{array}{c}0.890^{* * *} \\
(0.042)\end{array}$ & & & & \\
\hline Accounts $_{-1}$ & & & $\begin{array}{c}0.545^{* * *} \\
(0.087)\end{array}$ & $\begin{array}{c}0.478^{* * *} \\
(0.080)\end{array}$ & & \\
\hline NetIntMarg $_{-1}$ & & & & & $\begin{array}{c}0.401^{* * *} \\
(0.077)\end{array}$ & $\begin{array}{c}0.349^{* * *} \\
(0.096)\end{array}$ \\
\hline GDP growth & $\begin{array}{c}0.076 \\
(0.209)\end{array}$ & $\begin{array}{c}0.191 \\
(0.211)\end{array}$ & $\begin{array}{c}0.558 \\
(0.518)\end{array}$ & $\begin{array}{c}0.419 \\
(0.511)\end{array}$ & & \\
\hline External Debt & $\begin{array}{l}-0.047 \\
(0.054)\end{array}$ & $\begin{array}{c}-0.134^{* * *} \\
(0.037)\end{array}$ & & & & \\
\hline Inflation & $\begin{array}{c}-0.249^{* * *} \\
(0.044)\end{array}$ & $\begin{array}{l}-0.194 \\
(0.230)\end{array}$ & $\begin{array}{c}0.284 \\
(0.329)\end{array}$ & $\begin{array}{l}-0.022 \\
(0.401)\end{array}$ & $\begin{array}{c}0.187 \\
(0.331)\end{array}$ & $\begin{array}{c}2.477 \\
(1.843)\end{array}$ \\
\hline$M V P$ & & & $\begin{array}{l}-0.057 \\
(0.054)\end{array}$ & $\begin{array}{l}-0.050 \\
(0.067)\end{array}$ & & \\
\hline NEER & & & & & $\begin{array}{l}-0.166 \\
(0.812)\end{array}$ & $\begin{array}{l}-0.752 \\
(1.375)\end{array}$ \\
\hline Foreign Banks & $\begin{array}{l}-0.001 \\
(0.001)\end{array}$ & $\begin{array}{c}-0.002^{* * *} \\
(0.001)\end{array}$ & & & $\begin{array}{c}0.002 \\
(0.010)\end{array}$ & $\begin{array}{c}0.043^{* * *} \\
(0.016)\end{array}$ \\
\hline Institutions & $\begin{array}{c}0.013 \\
(0.056)\end{array}$ & $\begin{array}{l}0.065^{*} \\
(0.039)\end{array}$ & $\begin{array}{c}0.146 \\
(0.112)\end{array}$ & $\begin{array}{c}0.210 \\
(0.138)\end{array}$ & & \\
\hline KaOpen & & & & & $\begin{array}{l}-0.831 \\
(0.510)\end{array}$ & $\begin{array}{c}0.375 \\
(0.481)\end{array}$ \\
\hline Banking Crisis & $\begin{array}{c}-0.101^{* * *} \\
(0.032)\end{array}$ & $\begin{array}{c}-0.126^{* * *} \\
(0.042)\end{array}$ & $\begin{array}{c}0.200 \\
(0.259)\end{array}$ & $\begin{array}{c}0.481 \\
(0.296)\end{array}$ & $\begin{array}{c}-0.677^{* *} \\
(0.288)\end{array}$ & $\begin{array}{l}-0.336 \\
(0.423)\end{array}$ \\
\hline$G D P p c$ & & & $\begin{array}{c}0.257^{* * *} \\
(0.079)\end{array}$ & $\begin{array}{c}0.311^{* * *} \\
(0.099)\end{array}$ & $\begin{array}{c}-0.331^{* *} \\
(0.155)\end{array}$ & $\begin{array}{c}-0.492^{* * *} \\
(0.154)\end{array}$ \\
\hline Transition & $\begin{array}{c}0.401^{* * *} \\
(0.129) \\
\end{array}$ & $\begin{array}{c}0.186^{* *} \\
(0.079) \\
\end{array}$ & $\begin{array}{c}0.248 \\
(0.348) \\
\end{array}$ & $\begin{array}{l}-0.100 \\
(0.453)\end{array}$ & & \\
\hline Obs & 1,298 & 974 & 556 & 550 & 1,298 & 896 \\
\hline Countries & 77 & 74 & 61 & 60 & 75 & 72 \\
\hline $\operatorname{Max} \mathrm{T}$ & 19 & 14 & 11 & 11 & 21 & 13 \\
\hline Avg T & 17 & 13 & 9 & 9 & 17 & 12 \\
\hline Instruments & 146 & 125 & 150 & 129 & 146 & 125 \\
\hline $\mathrm{AB}-\mathrm{AR}(1) \mathrm{p}-\mathrm{val}$ & 0.000 & 0.001 & 0.046 & 0.077 & 0.000 & 0.001 \\
\hline $\mathrm{AB}-\mathrm{AR}(2) \mathrm{p}$-val & 0.708 & 0.647 & 0.489 & 0.789 & 0.489 & 0.789 \\
\hline Hansen p-val & 1.000 & 1.000 & 1.000 & 1.000 & 1.000 & 0.996 \\
\hline $\begin{array}{l}\text { Note: Dependent } \\
\text { System GMM estin } \\
\text { symbols }{ }^{* * *},{ }^{* *} \text { a }\end{array}$ & $\begin{array}{l}\text { bles: } \ln (\operatorname{Pr} \\
\text { ns where do } \\
\text { denote sigr }\end{array}$ & $\begin{array}{l}\text { Credit/G } \\
\text { ization anc } \\
\text { ance at the } \\
\text { dummi }\end{array}$ & $\begin{array}{l}\ln (\text { Accour } \\
\text { leterminar } \\
5 \% \text { and } 1 \\
\text { d a const }\end{array}$ & $\begin{array}{l}1000 \text { ad } \\
\text { evels, rest }\end{array}$ & $\begin{array}{l}\text { and Net } \\
\text { Robust S } \\
\text { ely. Mode }\end{array}$ & $\begin{array}{l}\text { est Margin. } \\
\text { parentheses, } \\
\text { clude time }\end{array}$ \\
\hline
\end{tabular}


Table 4. Deposit Dollarization and Financial Depth, Access and Efficiency with FE and Difference GMM estimators

\begin{tabular}{|c|c|c|c|c|c|c|}
\hline & \multicolumn{2}{|c|}{ Private credit / GDP } & \multicolumn{2}{|c|}{ Accounts } & \multicolumn{2}{|c|}{ Net Interest Margin } \\
\hline & $\mathrm{FE}$ & Diff GMM & $\mathrm{FE}$ & Diff GMM & $\mathrm{FE}$ & Diff GMM \\
\hline DepDol & $\begin{array}{c}-0.155^{*} \\
(0.070)\end{array}$ & $\begin{array}{c}-0.441^{*} \\
(0.203)\end{array}$ & $\begin{array}{c}-0.430^{*} \\
(0.234)\end{array}$ & $\begin{array}{c}-0.614^{*} \\
(0.356)\end{array}$ & $\begin{array}{c}0.630 \\
(0.818)\end{array}$ & $\begin{array}{l}3.479^{*} \\
(2.027)\end{array}$ \\
\hline PrivCred $_{-1}$ & $\begin{array}{c}0.817^{* \cdots} \\
(0.022)\end{array}$ & $\begin{array}{c}\left(0.730^{*} \cdots\right. \\
(0.056)\end{array}$ & & & & \\
\hline Accounts-1 & & & $\begin{array}{c}0.694^{\cdots} \cdots \\
(0.058)\end{array}$ & $\begin{array}{c}0.494^{* *} \\
(0.094)\end{array}$ & & \\
\hline NetIntMarg-1 & & & & & $\begin{array}{c}0.397^{* \cdots} \\
(0.057)\end{array}$ & $\begin{array}{c}0.342^{* \cdots} \\
(0.075)\end{array}$ \\
\hline GDP growth & $\begin{array}{c}0.190 \\
(0.192)\end{array}$ & $\begin{array}{l}-0.132 \\
(0.313)\end{array}$ & $\begin{array}{c}0.391 \\
(0.333)\end{array}$ & $\begin{array}{c}0.690 \\
(0.578)\end{array}$ & $\begin{array}{c}1.099 \\
(1.331)\end{array}$ & $\begin{array}{c}3.214 \\
(3.789)\end{array}$ \\
\hline Inflation & $\begin{array}{c}-0.222^{*} \\
(0.069)\end{array}$ & $\begin{array}{c}-0.365^{*} \\
(0.130)\end{array}$ & $\begin{array}{l}0.061^{\circ} \\
(0.036)\end{array}$ & $\begin{array}{l}0.224^{*} \\
(0.104)\end{array}$ & $\begin{array}{c}-0.695^{\circ} \\
(0.254)\end{array}$ & $\begin{array}{c}-0.466 \\
(0.379)\end{array}$ \\
\hline$M V P$ & $\begin{array}{c}0.004 \\
(0.006)\end{array}$ & $\begin{array}{c}0.002 \\
(0.007)\end{array}$ & $\begin{array}{c}-0.135^{\circ} \\
(0.081)\end{array}$ & $\begin{array}{c}-0.133^{\circ} \\
(0.071)\end{array}$ & $\begin{array}{c}0.016 \\
(0.063)\end{array}$ & $\begin{array}{c}0.119 \\
(0.094)\end{array}$ \\
\hline REER Cycl. & $\begin{array}{c}0.013 \\
(0.008)\end{array}$ & $\begin{array}{l}0.018^{\circ} \\
(0.011)\end{array}$ & $\begin{array}{c}0.006 \\
(0.016)\end{array}$ & $\begin{array}{l}-0.029 \\
(0.028)\end{array}$ & $\begin{array}{l}-0.037 \\
(0.101)\end{array}$ & $\begin{array}{l}-0.201 \\
(0.151)\end{array}$ \\
\hline NEER & $\begin{array}{l}0.058^{\circ} \\
(0.031)\end{array}$ & $\begin{array}{c}0.196^{*} \\
(0.057)\end{array}$ & $\begin{array}{c}-0.013 \\
(0.073)\end{array}$ & $\begin{array}{l}-0.015 \\
(0.134)\end{array}$ & $\begin{array}{l}-0.335 \\
(0.355)\end{array}$ & $\begin{array}{l}-0.547 \\
(0.746)\end{array}$ \\
\hline Foreign Banks & $\begin{array}{c}0.000 \\
(0.001)\end{array}$ & $\begin{array}{l}0.003^{*} \\
(0.002)\end{array}$ & $\begin{array}{c}-0.001 \\
(0.001)\end{array}$ & $\begin{array}{c}0.001 \\
(0.003)\end{array}$ & $\begin{array}{c}0.002 \\
(0.007)\end{array}$ & $\begin{array}{l}-0.008 \\
(0.021)\end{array}$ \\
\hline Institutions & $\begin{array}{c}0.088^{*} \\
(0.040)\end{array}$ & $\begin{array}{c}0.205^{* \cdots} \\
(0.065)\end{array}$ & $\begin{array}{c}0.132 \\
(0.113)\end{array}$ & $\begin{array}{c}0.166 \\
(0.199)\end{array}$ & $\begin{array}{l}-0.594 \\
(0.387)\end{array}$ & $\begin{array}{l}-1.171 \\
(0.827)\end{array}$ \\
\hline 3 Bank Conc. & $\begin{array}{c}-0.102 \\
(0.063)\end{array}$ & $\begin{array}{l}-0.101 \\
(0.088)\end{array}$ & $\begin{array}{c}-0.066 \\
(0.125)\end{array}$ & $\begin{array}{c}0.060 \\
(0.153)\end{array}$ & $\begin{array}{c}0.792 \\
(0.626)\end{array}$ & $\begin{array}{l}3.007^{\circ} \\
(1.539)\end{array}$ \\
\hline KaOpen & $\begin{array}{c}0.034 \\
(0.042)\end{array}$ & $\begin{array}{c}0.074 \\
(0.062)\end{array}$ & $\begin{array}{l}-0.013 \\
(0.093)\end{array}$ & $\begin{array}{c}0.047 \\
(0.096)\end{array}$ & $\begin{array}{l}-0.298 \\
(0.440)\end{array}$ & $\begin{array}{c}0.316 \\
(0.683)\end{array}$ \\
\hline External Debt & $\begin{array}{c}-0.049^{\circ} \\
(0.025)\end{array}$ & $\begin{array}{c}0.005 \\
(0.082)\end{array}$ & $\begin{array}{l}-0.081 \\
(0.064)\end{array}$ & $\begin{array}{l}-0.122 \\
(0.096)\end{array}$ & $\begin{array}{c}0.089 \\
(0.309)\end{array}$ & $\begin{array}{l}-0.552 \\
(0.766)\end{array}$ \\
\hline Banking Crisis & $\begin{array}{c}-0.077^{*} \cdot . \\
(0.026)\end{array}$ & $\begin{array}{c}-0.072^{*} \\
(0.037)\end{array}$ & $\begin{array}{l}0.061^{\circ} \\
(0.036)\end{array}$ & $\begin{array}{l}0.224^{* *} \\
(0.104)\end{array}$ & $\begin{array}{c}-0.695^{*} \\
(0.254)\end{array}$ & $\begin{array}{l}-0.466 \\
(0.379)\end{array}$ \\
\hline$G D P p c$ & 0.042 & -0.083 & 0.083 & $\begin{array}{c}0.456 \\
(0.581)\end{array}$ & 0.657 & 2.879 \\
\hline Population & $\begin{array}{c}(0.056) \\
0.052 \\
(0.115)\end{array}$ & $\begin{array}{c}(0.194) \\
0.336 \\
(0.342)\end{array}$ & $\begin{array}{c}(0.177) \\
0.632 \\
(0.395)\end{array}$ & $\begin{array}{l}(0.281) \\
1.382^{*} \\
(0.787)\end{array}$ & $\begin{array}{c}(0.638) \\
0.782 \\
(1.028)\end{array}$ & $\begin{array}{c}(2.118) \\
-1.483 \\
(3.389)\end{array}$ \\
\hline Age Dep. Ratio & $\begin{array}{c}-0.125 \\
(0.128) \\
\end{array}$ & $\begin{array}{c}-0.378 \\
(0.573) \\
\end{array}$ & $\begin{array}{c}(0.395) \\
0.041 \\
(0.303) \\
\end{array}$ & $\begin{array}{c}0.799 \\
(0.751) \\
\end{array}$ & $\begin{array}{c}(1.028) \\
0.490 \\
(1.165) \\
\end{array}$ & $\begin{array}{c}(3.389) \\
-0.747 \\
(5.778) \\
\end{array}$ \\
\hline Obs & 1,216 & 1,163 & 538 & 429 & 1,192 & 1,058 \\
\hline Countries & 77 & 77 & 58 & 58 & 75 & 75 \\
\hline Max T & 19 & 18 & 11 & 9 & 19 & 17 \\
\hline Avg T & 16 & 15 & 9 & 7 & 16 & 14 \\
\hline $\bar{R}^{2}$ & 0.89 & & 0.87 & & 0.27 & \\
\hline Instruments & & 198 & & 215 & & 217 \\
\hline AB-AR(1) p-val & & 0.000 & & 0.033 & & 0.000 \\
\hline $\mathrm{AB}-\mathrm{AR}(2)$ p-val & & 0.475 & & 0.538 & & 0.575 \\
\hline Hansen p-val & & 1.000 & & 1.000 & & 1.000 \\
\hline
\end{tabular}

Note: Dependent variables: $\ln ($ Private Credit/GDP), $\ln$ (Accounts per 1000 adults) and Net Interest Margin. Fixed effects (FE) and Difference GMM (Diff GMM) estimations where dollarization and its determinants are endogenous. Robust SE in parentheses, and symbols $\cdots, \cdots$ and ${ }^{*}$ denote significance at the $1 \%, 5 \%$ and $10 \%$ levels, respectively. Models include time dummies and a constant. 
Table 5. The Relationship between Dollarization and Financial Development in Countries with Deposit and Credit Dollarization Above 1 Percent

\begin{tabular}{|c|c|c|c|c|c|c|}
\hline & \multicolumn{2}{|c|}{ Private Credit / GDP } & \multicolumn{2}{|c|}{ Accounts } & \multicolumn{2}{|c|}{ Net Interest Margin } \\
\hline DepDol & $\begin{array}{c}-0.368^{* *} \\
(0.185)\end{array}$ & & $\begin{array}{c}0.223 \\
(0.305)\end{array}$ & & $\begin{array}{c}5.285^{* *} \\
(2.634)\end{array}$ & \\
\hline CredDol & & $\begin{array}{c}0.113 \\
(0.128)\end{array}$ & & $\begin{array}{l}-0.106 \\
(0.220)\end{array}$ & & $\begin{array}{l}-1.132 \\
(1.896)\end{array}$ \\
\hline PrivCredit $_{-1}$ & $\begin{array}{c}0.828^{* * *} \\
(0.052)\end{array}$ & $\begin{array}{c}0.862^{* * *} \\
(0.040)\end{array}$ & & & & \\
\hline Accounts-1 & & & $\begin{array}{c}0.761^{* * *} \\
(0.070)\end{array}$ & $\begin{array}{c}0.760^{* * *} \\
(0.075)\end{array}$ & & \\
\hline NetIntMarg $g_{-1}$ & & & & & $\begin{array}{c}0.327^{* * *} \\
(0.078)\end{array}$ & $\begin{array}{c}0.307^{* * *} \\
(0.095)\end{array}$ \\
\hline GDP growth & $\begin{array}{c}0.059 \\
(0.330)\end{array}$ & $\begin{array}{c}0.021 \\
(0.220)\end{array}$ & $\begin{array}{l}0.772^{*} \\
(0.466)\end{array}$ & $\begin{array}{l}0.801^{*} \\
(0.465)\end{array}$ & $\begin{array}{l}-0.033 \\
(2.363)\end{array}$ & $\begin{array}{c}2.043 \\
(2.463)\end{array}$ \\
\hline External Debt & $\begin{array}{l}-0.033 \\
(0.063)\end{array}$ & $\begin{array}{l}-0.023 \\
(0.071)\end{array}$ & $\begin{array}{c}-0.227^{*} \\
(0.116)\end{array}$ & $\begin{array}{l}-0.187 \\
(0.129)\end{array}$ & $\begin{array}{l}-0.671 \\
(0.813)\end{array}$ & $\begin{array}{l}-1.280 \\
(0.829)\end{array}$ \\
\hline Inflation & $\begin{array}{l}-0.192 \\
(0.196)\end{array}$ & $\begin{array}{c}-0.327^{* *} \\
(0.156)\end{array}$ & $\begin{array}{l}0.947^{*} \\
(0.484)\end{array}$ & $\begin{array}{l}1.011^{*} \\
(0.546)\end{array}$ & $\begin{array}{c}1.548 \\
(1.595)\end{array}$ & $\begin{array}{c}1.594 \\
(1.436)\end{array}$ \\
\hline$M V P$ & $\begin{array}{c}0.002 \\
(0.006)\end{array}$ & $\begin{array}{c}0.006 \\
(0.010)\end{array}$ & $\begin{array}{c}-0.264^{* *} \\
(0.132)\end{array}$ & $\begin{array}{c}-0.262^{* *} \\
(0.130)\end{array}$ & $\begin{array}{c}0.041 \\
(0.086)\end{array}$ & $\begin{array}{l}-0.003 \\
(0.113)\end{array}$ \\
\hline REER Cycl. & $\begin{array}{c}0.022 \\
(0.013)\end{array}$ & $\begin{array}{c}0.010 \\
(0.012)\end{array}$ & $\begin{array}{l}-0.010 \\
(0.031)\end{array}$ & $\begin{array}{l}-0.027 \\
(0.031)\end{array}$ & $\begin{array}{l}-0.244 \\
(0.163)\end{array}$ & $\begin{array}{l}-0.078 \\
(0.170)\end{array}$ \\
\hline NEER & $\begin{array}{c}0.076 \\
(0.055)\end{array}$ & $\begin{array}{c}0.177^{* * *} \\
(0.058)\end{array}$ & $\begin{array}{l}-0.135 \\
(0.160)\end{array}$ & $\begin{array}{l}-0.116 \\
(0.151)\end{array}$ & $\begin{array}{l}-0.260 \\
(0.848)\end{array}$ & $\begin{array}{r}-1.770^{*} \\
(0.986)\end{array}$ \\
\hline Foreign Banks & $\begin{array}{c}-0.003^{* *} \\
(0.001)\end{array}$ & $\begin{array}{c}-0.003^{* * *} \\
(0.001)\end{array}$ & $\begin{array}{l}-0.002 \\
(0.002)\end{array}$ & $\begin{array}{l}-0.002 \\
(0.003)\end{array}$ & $\begin{array}{c}0.033^{* *} \\
(0.017)\end{array}$ & $\begin{array}{c}0.046^{* *} \\
(0.022)\end{array}$ \\
\hline Institutions & $\begin{array}{c}0.065 \\
(0.058)\end{array}$ & $\begin{array}{c}0.106^{* *} \\
(0.053)\end{array}$ & $\begin{array}{c}0.136 \\
(0.103)\end{array}$ & $\begin{array}{c}0.079 \\
(0.096)\end{array}$ & $\begin{array}{l}-0.175 \\
(0.630)\end{array}$ & $\begin{array}{l}-0.561 \\
(0.857)\end{array}$ \\
\hline 3 Bank Conc. & $\begin{array}{c}-0.241^{*} \\
(0.140)\end{array}$ & $\begin{array}{l}-0.090 \\
(0.170)\end{array}$ & $\begin{array}{r}-0.578^{*} \\
(0.312)\end{array}$ & $\begin{array}{c}-0.637^{* *} \\
(0.314)\end{array}$ & $\begin{array}{c}0.751 \\
(1.475)\end{array}$ & $\begin{array}{l}3.370 \\
(2.055)\end{array}$ \\
\hline KaOpen & $\begin{array}{c}0.014 \\
(0.085)\end{array}$ & $\begin{array}{l}-0.063 \\
(0.066)\end{array}$ & $\begin{array}{l}-0.079 \\
(0.081)\end{array}$ & $\begin{array}{l}-0.056 \\
(0.080)\end{array}$ & $\begin{array}{l}-1.080 \\
(0.945)\end{array}$ & $\begin{array}{l}1.438^{*} \\
(0.766)\end{array}$ \\
\hline Banking Crisis & $\begin{array}{l}-0.047 \\
(0.037)\end{array}$ & $\begin{array}{c}-0.096^{* *} \\
(0.038)\end{array}$ & $\begin{array}{l}0.191^{*} \\
(0.116)\end{array}$ & $\begin{array}{c}0.210 \\
(0.137)\end{array}$ & $\begin{array}{l}-0.313 \\
(0.459)\end{array}$ & $\begin{array}{l}-0.127 \\
(0.465)\end{array}$ \\
\hline$G D P p c$ & $\begin{array}{l}-0.042 \\
(0.052)\end{array}$ & $\begin{array}{l}-0.018 \\
(0.027)\end{array}$ & $\begin{array}{c}0.057 \\
(0.045)\end{array}$ & $\begin{array}{c}0.070 \\
(0.044)\end{array}$ & $\begin{array}{l}-0.205 \\
(0.531)\end{array}$ & $\begin{array}{l}-0.344 \\
(0.334)\end{array}$ \\
\hline Population & $\begin{array}{l}-0.089 \\
(0.057)\end{array}$ & $\begin{array}{l}-0.027 \\
(0.053)\end{array}$ & $\begin{array}{l}-0.129 \\
(0.079)\end{array}$ & $\begin{array}{c}-0.181^{* *} \\
(0.082)\end{array}$ & $\begin{array}{c}0.062 \\
(0.584)\end{array}$ & $\begin{array}{c}0.875 \\
(0.700)\end{array}$ \\
\hline Age Dep. Ratio & $\begin{array}{l}-0.062 \\
(0.430)\end{array}$ & $\begin{array}{c}0.033 \\
(0.250)\end{array}$ & $\begin{array}{l}-0.352 \\
(0.335)\end{array}$ & $\begin{array}{l}-0.302 \\
(0.281)\end{array}$ & $\begin{array}{l}-0.535 \\
(4.534)\end{array}$ & $\begin{array}{c}0.203 \\
(2.356)\end{array}$ \\
\hline Transition & $\begin{array}{c}0.286 \\
(0.205) \\
\end{array}$ & $\begin{array}{c}0.213 \\
(0.145) \\
\end{array}$ & $\begin{array}{l}-0.092 \\
(0.204) \\
\end{array}$ & $\begin{array}{l}-0.099 \\
(0.195) \\
\end{array}$ & $\begin{array}{l}-2.488 \\
(2.446) \\
\end{array}$ & $\begin{array}{c}0.594 \\
(1.698) \\
\end{array}$ \\
\hline Obs & 1,022 & 777 & 405 & 399 & 945 & 713 \\
\hline Countries & 63 & 60 & 49 & 48 & 62 & 59 \\
\hline $\operatorname{Max} T$ & 19 & 14 & 10 & 10 & 18 & 13 \\
\hline Avg T & 16 & 13 & 8 & 8 & 15 & 12 \\
\hline Instruments & 200 & 179 & 218 & 197 & 255 & 234 \\
\hline AB-AR(1) p-val & 0.000 & 0.012 & 0.027 & 0.027 & 0.000 & 0.006 \\
\hline $\mathrm{AB}-\mathrm{AR}(2) \mathrm{p}$-val & 0.813 & 0.575 & 0.785 & 0.813 & 0.632 & 0.592 \\
\hline Hansen p-val & 1.000 & 1.000 & 1.000 & 1.000 & 1.000 & 1.000 \\
\hline $\begin{array}{l}\text { Note: Dependent } \\
\text { System GMM estim } \\
\text { and symbols }{ }^{* * *},{ }^{* *}\end{array}$ & $\begin{array}{l}\text { les: } \ln (1 \\
\text { is where } \\
{ }^{*} \text { denote }\end{array}$ & $\begin{array}{r}\text { Credit/G } \\
\text { zation and } \\
\text { cance at } \mathrm{t} \\
\text { dummi }\end{array}$ & $\begin{array}{l}\ln (\text { Accol } \\
\text { letermin } \\
6,5 \% \text { an } \\
\text { d a cons }\end{array}$ & $\begin{array}{l}\text { oer } 1000 \text { ac } \\
\text { are endoge } \\
\% \text { levels, } r\end{array}$ & $\begin{array}{l}\text { and Net } \\
\text { Robust } \\
\text { tively. Mc }\end{array}$ & $\begin{array}{l}\text { est Margin. } \\
\text { parentheses, } \\
\text { include time }\end{array}$ \\
\hline
\end{tabular}

